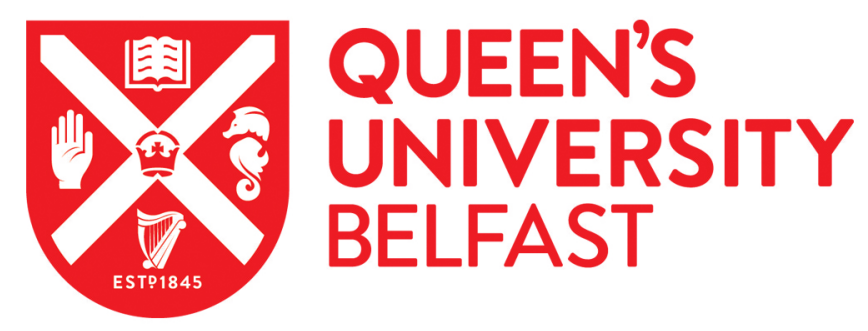

\title{
Tropical limestone forest resilience and late Pleistocene foraging during MIS-2 in the Tràng An massif, Vietnam
}

Rabett, R. (2017). Tropical limestone forest resilience and late Pleistocene foraging during MIS-2 in the Tràng An massif, Vietnam. Quaternary International, 448, 62-81. https://doi.org/10.1016/j.quaint.2016.06.010

\section{Published in:}

Quaternary International

\section{Document Version:}

Peer reviewed version

Queen's University Belfast - Research Portal:

Link to publication record in Queen's University Belfast Research Portal

\section{Publisher rights}

(C) 2016 Elsevier Ltd.

This manuscript is distributed under a Creative Commons Attribution-NonCommercial-NoDerivs License

(https://creativecommons.org/licenses/by-nc-nd/4.0/), which permits distribution and reproduction for non-commercial purposes, provided the author and source are cited.

\section{General rights}

Copyright for the publications made accessible via the Queen's University Belfast Research Portal is retained by the author(s) and / or other copyright owners and it is a condition of accessing these publications that users recognise and abide by the legal requirements associated with these rights.

Take down policy

The Research Portal is Queen's institutional repository that provides access to Queen's research output. Every effort has been made to ensure that content in the Research Portal does not infringe any person's rights, or applicable UK laws. If you discover content in the Research Portal that you believe breaches copyright or violates any law, please contact openaccess@qub.ac.uk. 


\title{
TROPICAL LIMESTONE FOREST RESILIENCE AND LATE PLEISTOCENE FORAGING DURING MIS-2 IN THE TRÀNG AN MASSIF, VIETNAM
}

${ }^{+1}$ Rabett, R., ${ }^{2}$ Ludgate, N., ${ }^{3}$ Stimpson, C., ${ }^{1}$ Hill, E., ${ }^{4}$ Hunt, C., ${ }^{5}$ Ceron, J., ${ }^{6}$ Farr, L., ${ }^{7}$ Morley, M., ${ }^{8}$ Reynolds, T., ${ }^{6}$ Zukswert, H., ${ }^{1}$ Simpson, D., ${ }^{10}$ Nyiri, B., ${ }^{11}$ Verhoeven, M., ${ }^{10}$ Appleby, J., ${ }^{1}$ Meneely, J., ${ }^{6}$ Phan, L., ${ }^{6}$ Dong, N-N., ${ }^{10}$ Lloyd-Smith, L., ${ }^{13}$ Hawkes, J. ${ }^{14}$ Blyth, A., ${ }^{15}$ Nguyêń Cao Tâń

${ }^{1}$ School of Geography, Archaeology \& Palaeoecology, Queen's University Belfast, Elmwood Avenue, Belfast BT7 1NN, UK

${ }^{2}$ School of Geography, Queen Mary University of London, Mile End Road, London E1 4NS

${ }_{3}^{3}$ Palaeontology Research Laboratory for Archaeology and the History of Art, University of Oxford, South Parks Road, Oxford OX1 3QY, UK

${ }^{4}$ School of Natural Sciences \& Psychology, Liverpool John Moores University, Byrom Street, Liverpool L3 3AF, UK

${ }^{5}$ Department of Anthropology \& Archaeology, University of Otago, PO Box 56, Dunedin 9054, New Zealand

${ }^{6}$ Division of Archaeology, University of Cambridge, Downing Street, Cambridge CB2 3DZ, UK

${ }^{7}$ Centre for Archaeological Science, University of Wollongong, Northfields Avenue, Wollongong NSW 2522 Australia

${ }^{8}$ Birkbeck College, Faculty of Continuing Education, 26 Russell Square, London WC1B 5DQ, UK

${ }^{10}$ School of Archaeology and Ancient History, University of Leicester, University Road, Leicester, LE1 7RH, $U K$

${ }^{11}$ RAAP Archaeological Consultancy, De Savornin Lohmanstraat 11, 6004 AM Weert, The Netherlands

${ }^{13}$ Department of Asia, The British Museum, Great Russell Street, London, WC1B 3DG, UK

${ }^{14}$ Department of Chemistry, Organic and Isotope Geochemistry Centre, Bentley Campus, Curtin University, GPO Box U1987 Perth, Western Australia 6845, Australia

${ }^{15}$ Tràng An Landscape Complex Management Board, Ninh Bình, Ninh Bình province, Vietnam

+ Corresponding author: $\underline{\text { r.rabett@qub.ac.uk }}$

\begin{abstract}
In this paper we present a multi-proxy study of tropical limestone forest and its utilization by human groups during the major climatic and environmental upheavals of MIS-2 (29-11.7 kBP). Our data are drawn from new field research within the Tràng An World Heritage property on the edge of the Red River Delta, northern Vietnam. Key findings from this study include 1) that limestone forest formations were resilient to the large-scale landscape transformation of the Sunda continent at the end of the last glaciation; ${ }^{2}$ that prehistoric human groups were probably present in this habitat through-out MIS-2; and ${ }^{3)}$ that the forested, insular, karst of Tràng An provided foragers with a stable resource-base in a wider changing landscape. These results have implications for our understanding of the prehistoric utilization of karst environments, and resonance for their conservation in the face of climate and environmental change today.
\end{abstract}

Keywords: limestone forest, resilience, MIS-2, tropical foragers, refugium, conservation

Quaternary International (in press) http://dx.doi.org/10.1016/j.quaint.2016.06.010 


\section{INTRODUCTION}

Profound climate and landscape changes were witnessed at a global scale during Marine Isotope Stage 2 (MIS-2) 29-11.7 cal. kBP. As conditions deteriorated into the Last Glacial Maximum (LGM) 26-19 cal. kBP (Clark et al. 2009) heightened aridity was experienced in many parts of the dry tropics (e.g. Weyhenmeyer et al. 2000; Barton et al. 2005; Cook 2009). Both here and at higher latitudes (that were more directly under the influence of LGM icesheet expansion) biotic and human communities tended to contract into refugial enclaves (see e.g. Pala et al. 2012; Rose et al. 2013; Williams et al. 2013; Husemann et al. 2014).

While the effects of the LGM were more muted in the humid tropics of Southeast Asia (e.g. Huang et al. 1997; Pelejero et al. 1999; Visser et al. 2003; Shintani et al. 2011) local marine, terrestrial and lacustrine archives indicate that changes in regional precipitation and vegetation cover did, nonetheless, occur (Huang et al. 1997; Sun \& Li 1999; Sun et al. 2000). In the post-LGM late glacial especially, climatic variability and environmental changes had farreaching and transformative effects on Pleistocene landscapes. The increased aridity associated with Heinrich Event 1 (H1) (c. 17.5-14.7 cal. kBP) brought tangible climatic impact (Wang et al. 2001; Huang et al. 2011; Marwick \& Gagan 2011; Standford et al. 2011; Partin et al. 2015). The final resurgence of near-fully glacial conditions during GS-1 (Younger Dryas) 12.7-11.7 cal. $\mathrm{kBP}$ in the circum-Atlantic does not seem to have impacted on equatorial latitudes in Southeast Asia (Partin et al. 2007), though its effect at more northerly tropical latitudes is tenable (Huang et al. 2011).

The process of deglaciation also initiated sustained sea-level rise and flooding of regional coasts. With rates of inundation ranging from c. $0.4 \mathrm{~m}$ to as much as $5.0 \mathrm{~m}$ per 100 years, the effect on human and biological communities would have been considerable in Southeast Asia (Hanebuth et al. 2000; 2009; Kienast et al. 2003; Schimanski \& Stattegger 2005; Verleyehn et al. 2005; Soares et al. 2008; Kopp 2012; Hunt \& Gilbertson 2014). Ultimately, c. 75 per cent of the region's low-lying Pleistocene landmass, 'Sunda Land' (Molengraaf \& Weber 1921) - incorporating the Greater Sunda Islands (Borneo, Sumatra and Java) together with numerous smaller islands and island chains, which extended Asia into the Southern Hemisphere - was submerged by the mid-Holocene. Across this continent and latter-day archipelago, limestone karst environments have played a prominent role in early human and archaic hominin occupation for almost a hundred millennia (e.g. Brown et al. 2004; Yi et al. 2008; van den Bergh et al. 2009; Mijares et al. 2010; Rabett 2012; Stimpson 2012; Barker 2013).

Investigation of karstic habitats in northern Vietnam has been closely tied to one particular palaeo-cultural entity: the 'Hoabinhian'. Variously described as, a Mesolithic culture (e.g. Matthews 1966), a 'technocomplex' (e.g. Gorman 1970; Forestier et al. 2015) reflecting a common ecological adaptation, or an industry (see Shoocongdej 1996), it is now argued that the Hoabinhian represents the most important point of cultural reference for the late glacial occupation of the seasonal tropics (Ji et al. in press). It is certainly the case that it has featured conspicuously in our understanding of early human adaptation to these environments through almost a century of research (Gorman 1970, 1971; Reynolds 1989; Ha Van Tan 1997; Shoocongdej 1996; Rabett 2012). Despite this attention, the significant technological and subsistence variability that exists within the Hoabinhian continues to be a point of debate and reinterpretation (e.g. Rabett et al. 2011; Marwick 2013; Forestier et al. 2013, 2015). Although generally considered to have emerged as a distinct technological system during, or soon after, the LGM, lasting into the Holocene, the duration of the Hoabinhian and its geographic extent (e.g. Shoocongdej 1996; Ji et al. in press) are also yet to 
be formally agreed upon. Its heartland, though, continues to be situated today, much as it was following initial discoveries by Patte in 1923 and Colani and Mansuy (1926-31): in the forest-clad karstic hills of northern Vietnam; and its emergence coming through the process of living in that environment.

Tropical limestone forests differ significantly in structure and species composition from other tropical forest formations (Sterling et al. 2006). The insular and refugial character they exhibit reflects high levels of biodiversity and species endemism (e.g. Adam \& Mamat 2005; Clements et al. 2006, 2008; Sodhi et al. 2007; Furey et al. 2010; Gao et al. 2015). Soils are generally thin, poor in most minerals and nutrients, and derived directly from the underlying limestone. Modern precipitation levels in the northern sub-tropics, close to the Song Hong River delta of Vietnam, are concentrated (c. 80\%) during the southwest monsoon between May and October, where receipt of rainfall ranges from 1300-1800 mm (Li et al. 2006b). The colder and drier northeast monsoon between November and April brings much lower levels of annual rainfall: 200-250 mm (Do Cong Thung 2014). Surface water run-off is often rapid in karst landscapes. This has the effect of heightening local aridity. Surface water accumulation in poorly drained locales, though, can lead to the formation of acidic peat, leading to the creation of varied microhabitats and the ability of limestone areas to host vegetative components adapted to a range of different conditions (Sterling et al. 2006). While precipitation arrives with marked monsoon seasonality and is often poorly retained for plant-life at sub-tropical latitudes, compared to their southern lowland rainforest counterparts (Chang et al., 2005) summer insolation levels are routinely more intense than those experienced closer to the Equator (Paillard et al. 1996; Wang \& Enfield 2001). This combination has a profound effect on the production of plant $n$-alkanes and $n$-alkanoic acids that can be tracked and through them past environmental conditions can be reconstructed (Rommerskirchen et al. 2003).

The particular association of northern Vietnam's palaeo-cultural record with tropical limestone forest emphasises that greater consideration needs to be made of the diversity that exists in tropical forest ecologies and the impact this has had on the history and scope of human adaptation (e.g. Roberts \& Petraglia 2015). With recent claims that less is currently known about human adaptive capacities than about the responses to climate change by many natural systems (IPCC 2007-II), examining the long-term relationship between humans and tropical forest habitats offers considerable potential to enhance our understanding of the diversity of socio-cultural responses to climate-driven environmental change. In this paper we present a multi-proxy terrestrial record from the cave site of Hang Trống, located in an isolated limestone massif on the western edge of the Song Hong (Red River) delta, Vietnam. This record spans the last twelve thousand years of MIS-2 and affords a rare opportunity to assess the local impact of late glacial climate and environmental change on northern tropical limestone forest; also to consider the significance of this habitat to early human settlement of the area; and to explore the potential value of such Pleistocene records to modern conservation management. The Tràng An limestone massif, where this study is set, is recognized internationally as an exemplar of the combined natural and cultural heritage value preserved within such landscapes.

\section{TRÀNG AN LANDSCAPE COMPLEX}

This World Heritage property is situated within the province of Ninh Bính in northern Vietnam, on the southern margin of the Song Hong (Red River) Delta, and is centred on an isolated massif of Upper Palaeozoic massively-bedded limestone karst of shallow marine 
lagoon and reef origin (figure 1). The core property is forested and covers 6226 hectares or $62.2 \mathrm{~km}^{2}$ (surrounded by a buffer zone of 6026 hectares, of mostly rural land with rice paddy fields). Tràng An is administered by the Ninh Binh Province People's Committee and a semi-autonomous management board. The property exemplifies an outstanding humid tropical tower-karst landscape in the final stages of geomorphic evolution, comprising karst cones and towers, enclosed depressions and an intricate system of fresh water-filled footcaves. Although currently emergent, this landscape has been invaded by the sea several times in the recent geological past and is often compared to the flooded tower karst seascape of Halong Bay. Tràng An's inscription also recognizes its prehistoric archaeology, which spans in excess of the last 30,000 years and contains one of the country's oldest archaeological sites: Hang Trống.

\section{$<$ Figure $1 \gg$}

\section{HANG TRỐNG}

The cave site of Hang Trống (20.250444N, 105.890111E) is situated approximately 142.3 metres above sea level, and $60 \mathrm{~m}$ below the apex of a limestone karst tower in the central part of the Tràng An massif. The cave forms a tunnel that is orientated along a north-south axis through the apex, with a total exposed floor area of $c .170 \mathrm{~m}^{2}$ (figure 2). Hang Trống's elevated position, coupled with a marked difference in the size of its two apertures, promotes air flow, accelerating it substantially when winds are northerly. Aeolian processes have been a significant force in site formation: affecting not only rates of deposition but also rates of the erosion and transportation of sediments from the cave (probably exiting via the southern aperture). The noticeable loss of $c .1 \mathrm{~m}$ of sediment (indicated by surviving material adhering to the walls), was probably lost through a mix of hydrological and aeolian erosion.

\section{$<<$ Figure $2>>$}

\subsection{Chronology}

Radiocarbon dates have been obtained using the accelerator mass spectrometer (AMS) at the 14CHRONO Centre, Queen's University, Belfast (table $1-{ }^{14} \mathrm{C}$ ages were calibrated by Calib 6.0 on the $2^{\text {nd }}$ January 2013, using the INTCAL09 calibration curve, Reimer et al. 2009). All ages are quoted in calibrated age before present (BP), with BP being AD $1^{\text {st }}$ January 1950; the abbreviation ' $\mathrm{kBP}$ ' is used to describe calibrated thousands of years. Aside from one surfacemodern age from mixed deposits, all ${ }^{14} \mathrm{C}$ dates are in sequence (see figure 3 ) and demonstrate the potential for accurately determining a time-depth profile at the site, pushing evidence of human occupation here deep into the LGM. The aeolian processes at work within Hang Trống have probably aided the chronological stratigraphy, bringing sediments in to Hang Trống regularly and preventing post-depositional mixing of the shell midden. The onset of the LGM coincides with the base of excavation (2010) in Trench 1.

$\ll$ Table $1 \gg$

\section{METHODOLOGIES AND RESULTS}

Hang Trống was surveyed using a Geo Fennell 20x automatic level and mapped at high resolution using a Leica HDS3000 LiDAR scanner. Systematic excavation began in the 
middle of the cave with Trench 1 in 2009 and then, in the second season (2010), concurrently in two additional trenches, Trenches 2 and 3, close to the western and eastern walls, respectively (figure 3) (see Rabett 2013). All three trenches contained cultural evidence, including hearths. In addition to macroscopic data from these material remains, geochemical analysis was undertaken on the sediments (and shell), providing a multi proxy approach to interpreting the location, its occupation and local environment.

\section{$<$ Figure $3>>$}

\subsection{Macro-botanical remains}

Samples of macro-botanical remains were collected from dry sieving (2 $\mathrm{mm}$ mesh) on site and also in bulk sediment samples that had been processed using bucket flotation $(1 \mathrm{~mm})$. Data on carbonized plant remains, in particular, provides a useful line of evidence on vegetation composition, fuel collection and plant processing strategies (Ceron n.d.). In each case samples were counted, weighed, measured and assessed for state of preservation. A total of 459 fragments were identified to family or higher taxonomic level (table 2). Specimens were mounted and photographed with a NIKON Eclipse Ci with 4x.15 to 100xA/1.25 magnification. The taxonomic identifications were based on comparisons with identified specimens, from the nearby Vietnamese Palaeolithic site of Con Moong (Nguyen Viet pers. comm. to Ceron 2011), from Ille Cave, Palawan (Carlos 2010; Ceron pers. observ.), on published material (Paz 2001), and with the assistance of the Forest Product Research and Development Institute (FPRDI), Los Baños, Laguna. Following established criteria relating to characteristics such as pore topography, tracheids and fibre (e.g. Thompson 1996; Ella et al. 2009) a pilot SEM study of four pieces of charred parenchymous material was also undertaken. The chosen material had been recovered through flotation from contexts: (8002), (8101), (8103) from Trench 1 at Hang Trống and from (8215) from Trench 2.

\section{$<<$ Table 2 macro-botanical $\gg>$}

\subsection{Palynology}

Sediment samples were collected from the north-facing section of Trench 1 for palynological analysis. The surface of the section was cut back to remove loose material and ensure there was no modern contamination. Palynological analysis has been widely used as a method to determine past vegetation history (e.g. Birks 1980; Birks \& Birks 1981). In upland cave sites the sediments are dry and highly oxic; unlike in water lain environments where available oxygen (and hence degradation) is limited. As a result pollen grains oxidize rapidly and/or become 'crumpled'. This level of degradation of pollen grains can pose problems to the reliability when standard palynological techniques (those applied here) are employed. Due to the high concentration of cyclophorids at the site, all samples were sieved to remove shell fragments prior to standard pollen analysis (after Fægri \& Iversen, 1989). Pollen was successfully found in all six of the samples investigated, though in varying concentrations as shown in table 3. Owing to the importance of aeolian processes in site formation here, the pollen record is likely to be drawn from a wide catchment, extending beyond Tràng An onto the plains that surround the massif.

Despite the degraded state of pollen at the site, unique identifying features could still be recognized (table 4). The top context sample (8000-8002) displays a considerably higher concentration of identifiable pollen than other contexts (a value of $60 \%$ recoverable 
identification). It is deduced that this better preservation is largely due to modern windblown pollen becoming trapped within the sediments as erosion and localised micro-redeposition of these takes place. Consequently, these data could provide an example of the modern vegetation surrounding the site, though admixture with Pleistocene sediments has probably distorted this picture. The underlying and, by comparison, undisturbed Pleistocene deposits exhibited a much reduced level of preservation, with only 2-6\% of recovered pollen being identifiable using standard preparation techniques. Nonetheless, a range of plant types was identified and provided a workable dataset.

\section{$<<$ Table 3 pollen counts $>>$}

\section{$\ll$ Table 4 pollen identification $\gg>$}

\subsection{Plant biogeochemical markers}

Cave locations can provide chemically stable environments suitable for the preservation of biogeochemical compounds from higher plants (Blyth et al. 2007; Huang et al. 2008). Plant biomarkers are released into the environment by plant metabolic processes and decomposition; they can be isolated from other organic molecules and used as environmental markers (see Eglinton \& Hamilton 1967; Van Bergen et al. 1997). n-Alkanes in plants are hydrocarbons that are mainly synthesized in the leaf wax for protection against incoming solar radiation (insolation), desiccation and pathogens (see e.g. Hadley 1980; Koch \& Ensikat 2008; Kosma et al. 2009). The longer the $n$-alkane chain length the more energy and resources are required for creation, but the greater the protection provided (Rommerskirchen et al. 2003). Within equatorial regions where insolation is high plants produce the long $n$-alkane chains, provided there is also sufficient moisture. During periods of climate change that place stress on plants, they either produce shorter $n$-alkane chain lengths or are unable to survive. n-Alkanes preserve well in Quaternary deposits, and as the environment and climate are important controls on chain length distribution, they can furnish an independent and complementary record into past conditions (Meyers \& Ishiwatari 1993; Schwark et al. 2002; Blyth et al. 2007; Ludgate 2013).

Bulk and compound-specific $\delta^{13} \mathrm{C}$ analyses of sedimentary organic carbon preserved $n$-alkanes and $n$-alkanoic acids and provide information about the photosynthetic pathway of the plants they derive from and, therefore, the environment in which the plant grew. Ranges in carbon isotope values represent plants using different photosynthetic pathways. The $\delta^{13} \mathrm{C}$ value can range from $c$. -35 to $c$. $-15 \%$ (relative to the Vienna Pee Dee Belemnite international standard) depending on a number of variables, including (but not limited to) plant genus, moisture stress or plant longevity (Quade et al. 1989; Lockheart et al. 1997). Plants using the $\mathrm{C}_{3}$ photosynthetic pathway require sufficient amounts of water during their growing season to photosynthesise and give $\delta^{13} \mathrm{C}$ values typically within the range $-25 \%$ o to -35\% (O'Leary 1981; Osborne \& Slack 2012). Plants that follow the $\mathrm{C}_{4}$ photosynthetic pathway (including, in particular, most grass families) are able to survive in more arid conditions. $\mathrm{C}_{4}$ plants have an average $\delta^{13} \mathrm{C}$ value of $-13 \%$ and range between $-12 \%$ to -16 \%o (O'Leary 1981; Osborne \& Slack 2012).

Rabett et al. (2011) demonstrate that plant biomarkers, preserved for over $10 \mathrm{kBP}$ in sediments at another cave site in Tràng An, Hang Boi (c. $1 \mathrm{~km}$ from Hang Trống), display similarity to the biomarkers of plants within the surrounding vegetation today. For the biogeochemical analysis at Hang Trống samples were collected from the North face of 
Trench 1 . The section surface was cleaned to remove cross-context contamination and some whole shells were removed to increase the mass of sediment. In the laboratory the bulk lipid fraction was soxhlet-extracted from the sediment using dichloromethane $(95 \%)$ and methanol (5\%) to maximise recovery (Banjoo \& Nelson 2005; Wang et al. 2010). The recovered organic matrix was then analysed using Agilent 6890 Series gas chromatogram coupled to an Agilent 5973 mass spectrometer (GC-MS). Chemstation software was utilised to identify and quantify the $n$-alkanes. $\delta^{13} \mathrm{C}$ values of $n$-Alkanoic acids was determined using Delta V Advantage ThermoFisher isotope-ratio mass spectrometer interfaced with GCIsolink Trace GC Combustion conversion system. n-Alkanes were removed using off-line chromatography and analysed for compound specific $\delta^{13} \mathrm{C}$ using Agilent gas chromatogram coupled to a Thermo MAT 253 isotope ratio mass spectrometer (GC-IR-MS). Sediment total organic carbon content and total organic carbon $\delta^{13} \mathrm{C}$ values were determined using a Thermo Flash High Temperature Elemental Analyzer (Flash EA) coupled to a Thermo MAT 253 isotope ratio mass spectrometer (IR-MS). All $\delta^{13} \mathrm{C}$ values were normalized to the Vienna Pee Dee Belemnite standard.

$n$-Alkanes recovered from sediments have a greater proportion of odd- $n$-alkane carbon chain lengths rather than even; indicating that the sediments at Hang Trống contain a robust plant-derived lipid signal, similar to that observed at Hang Boi. The most abundant $n$-alkanes (over $10 \%$ of the total measured) include $C_{29}, C_{31}$ and $C_{33}$, these are all known to be of higher plant origin and therefore of importance here. $n$-Alkane $\mathrm{C}_{31}$ is the most dominant through the sediment column, with an average value of $c .40$ per cent. This demonstrates that plants growing locally are subjected to some environmental stress (high levels of insolation) but, generally, the nutrients and water required for the growth of protective lipids occur in abundance. Percentage histograms of the samples (figure 4) demonstrate a consistent trend.

The $\delta^{13} \mathrm{C}$ value of $n$-alkanes and $n$-alkanoic acids recovered from cave sediments clearly indicate a $\mathrm{C}_{3}$ photosynthetic pathway and therefore plants that require comparatively moisture-rich conditions in which to thrive. The slightly higher $\delta^{13} \mathrm{C}$ value for bulk organic carbon within the sediments highlights that preserved organic material is likely to be derived from multiple sources, including microbial and anthropogenic (Kohn and Cerling 2002; Nguyen Tu 2011). Food sources introduced by early human groups into the cave from farther afield could, for example, have contributed a biasing factor in the recovery plant biomarkers - a vector for which we are seeking further clarification. Our current hypothesis, based on the available evidence, suggests that limestone forest similar to that seen around Hang Trống today has existed in the vicinity of the cave through-out MIS-2.

\section{$\ll$ Figure 4 >}

\subsection{Zooarchaeological evidence}

\subsubsection{Macro-vertebrate fauna}

Bones from larger vertebrates were a relatively infrequent component of the excavated material in all three trenches (table 5). Analysis of these assemblages showed them to be predominantly mammalian, highly fragmented, desiccated and in many cases coated with sediment adhered by calcium carbonate deposition. All recovered fragments $>5 \mathrm{~mm}$ in length were counted and wherever possible refitted. A total of 1031 fragments (hereafter, Number of Specimens: 'NSP') were recorded, of which a total of 85 (8.2\%) was found to be 
diagnostic (to element and taxa, hereafter, Number of Identified Specimens: 'NISP'). The majority was only identifiable to family, but in exceptional cases higher order identification were possible. Comparative materials included those held within the Grahame Clark laboratory, Cambridge, supplemented by collections of digital images and relevant textual sources (notably, Lekagul \& McNeely 1988). Despite the relatively low occurrence of bones, inspection of the data indicated that burnt fragments were present throughout the excavated sequence (figure $5 \&$ table 5). Both the high degree of fragmentation and the evidence of burning give us confidence in the anthropogenic origin of this material.

\section{$<<$ Table 5 vertebrate fauna $>>$}

\section{$<<$ Figure 5 composite section $\mathrm{T} 1$ >}

\subsubsection{Micro-vertebrate fauna}

On-site observations and the characteristics of ground surface concentrations of microvertebrate bone near the western wall of the cave strongly suggested that these assemblages accumulated via pellet deposition beneath a contemporary owl roosting site. This record provides a valuable taphonomic control for the range and density of micro-faunal remains recovered during on-site excavations, and how they are to be interpreted.

A total of 2517 bones were identified to element and order from a collected sample of the surface assemblages. Frog bones (Order: Anura) dominated $(n=2230 / 2517$, or $89 \%)$, with all identifiable ilia attributed to the genus Rana. All parts of the skeleton were represented and the bones exhibited minimal breakage and weathering, with no signs of burning or any marked damage from digestive acids (after Andrews 1990; Stahl 1996). The remainder of the sample comprised a minor component of small mammal bones, including Rattus sp., Mus sp., Suncus sp., and Eonycteris sp. as well as, as yet, unidentified fish remains. The taxonomic composition of the assemblage with its strong bias toward amphibians, combined with the relative size of the prey items, inferred from skeletal elements, suggests that the bones were accumulated by a species of fish owl (Bubo sp. syn. Ketupa sp.) (Zukswert 2014).

Prehistoric pellet deposition from generations of owls using this particular roost could also have been a pathway for the introduction of bones into the archaeological deposits of the site. However, inspection of the distribution of the small vertebrate component of assemblages recovered in the three excavated trenches from Hang Trông indicated that the majority was concentrated in the uppermost excavated contexts (table 5). We conclude that the small mammal component of the upper archaeological contexts is most likely the result of mixing between modern and Late Pleistocene material and, therefore, we used their presence as a taphonomic marker and proxy for disturbance. Notably, such evidence was mostly confined to the upper few centimetres of deposit indicative both, that contexts below these carried no more than minor mixing through this particular nonanthropogenic vector, and that the roosting site itself may be of comparatively recent age though still conceivably hundreds if not thousands of years in duration.

\subsubsection{Molluscs}

A stand-out feature of many Mainland Southeast Asian archaeological assemblages dating from the Late- to early Post-Pleistocene are riverine or terrestrial shell middens (Rabett et al. 2011). To explore the taxonomic diversity and frequencies of represented molluscs within the Hang Trống midden, with respect to changes in site formation and wider environmental 
conditions, a column was removed $(20 \times 10 \mathrm{~cm})$ from the north-facing section of Trench 1 to a depth of $1.33 \mathrm{~m}$ below the current ground surface (figure 5).

The majority of the species identified were terrestrial molluscs (table 6). This included three species from the genus Cyclophorus: Cyclophorus theodori, Cyclophorus unicus and Cyclophorus cf. cambodjiensis - all of which live on or around trees. In addition to Cyclophorus, other terrestrial species were also identified, namely Cryptozona cf. chrysoraphe, and Zonitidae cf. Oxychilus sp. A further two examples of gastropods were noted for which only genus level attributions could be made; Camaena sp. and Amphidromus sp. both favour trees and shrub habitats.

Little data is available in the literature for the habitats of Cryptozona cf. chrysoraphe, and Zonitidae cf. Oxychilus sp. other than that the genera concerned have affinities with woodland settings. They continue to be found locally. A small number of aquatic taxa were also identified: Unio spp. and Planorbis sp. both favour larger bodies of freshwater such as lakes, ponds and rivers; Cerithrium sp. and Ellobium aurisjudae can occupy a broad range of aquatic/semi-aquatic habitats including estuaries, mangroves, shallow water and rivers. Minimum Number of Individuals (MNI) counts were calculated on the basis of the largest number of identifiable parts present per sample (i.e. whole shells, with lip or tip intact; plus the highest number of fragmented lips or tips). Total unburnt and burnt shell MNI counts, plotted by depth, are presented for comparison against vertebrate faunal remains from Trench 1 in figure 5.

\section{$<<$ Table 6 mollusc $>$}

\subsection{Technological evidence}

Typological classification of Southeast Asian lithic assemblages has been hampered by the often amorphous character of the material. While types can and have been identified, the utility of this approach to Hoabinhian or Hoabinhian-like technologies has come into question (e.g. Reynolds 1990; Marwick 2008, Forestier et al. 2013). In an attempt to help address this issue, and to foster greater integration between technological actions and resource acquisition, the Hang Trống lithic assemblage was studied using technotypological (see Reynolds 1989) and attribute analysis (see Tostevin 2013) methodologies. Both concentrate on the way that lithics were manufactured and explore variability within assemblages rather than categorising them according to strict types. The former method emphasises distinguishing broad technological classes that group generally similar pieces; the latter emphasises the dynamic nature of the lithic reduction process and how that variability can be understood in relation to human adaptive strategies. The use of two complementary methods, applied by two different researchers, also helped us to control for biases in distinguishing artefacts from non-artefactual pieces. In what is an overwhelmingly coarse-grained assemblage, often without prominent bulbs of percussion or other clear markers of technological practice, we accepted that levels of observer variance may exceed 5-10\% (after Proffitt \& de la Torre 2014).

An initial techno-typological study of selected pieces from the 2009 excavations at the site (context 8016, Trench 1) has been published elsewhere (see Rabett 2012, figure 6:17). This material has since been returned to Vietnam and is not integrated into the current study as it was not feasible to conduct an attribute-based analysis of it. Briefly, this initial study identified a core rejuvenation flake with at least two or three previous hard-hammer flake removals; a blade-flake, possibly struck using a soft-hammer technique; a large, thick 
secondary flake with a plain platform - this piece had slight rounding along the distal edge and evidence on its dorsal surface that many small flakes had been removed prior to this one - and finally a 'steep-edged' core that may also have been used as a pounder. These pieces suggested on-site production, including basic core preparation and possible use of soft-hammer reduction. Both study samples covered herein are drawn from the most extensive period of excavations at the site (in 2010). Material studied consists of, that recovered from LGM deposits in the lower half of Trench 1 (8201-8111) and post-LGM (MIS2) deposits (and likely post-LGM deposits) from trenches 3 and 2, respectively.

Techno-typological analysis identified $n=74$ modified pieces (table 7 ), with a further 13 of ambiguous classification. The industry to be based on single-platformed hard hammer reduction, with no evidence for core preparation, platform edge maintenance or platform preparation. There are a small number of siret flakes that may derive from the use of larger or heavier hammers (siret flakes are split longitudinally through the bulb of percussion). Secondary and tertiary flakes dominate the sample, indicative of non-intensive use of materials and possibly the reduction of materials elsewhere (either on site or off site). The formal flake tool-type list is limited to two scrapers and a burin (table 7, artefacts 11 [from cleaning], $17 \& 42$, respectively). The pebble-based portion of the inventory includes a hammer/pounder with patches of hammering, pitting and micro-flaking on both ends. Seven pieces were defined as 'short-axe' fragments (see figure 6), following the northern Vietnamese typological nomenclature for the Hoabinhian. Attribute analysis of the sample (Phan 2014, Appendix B) identified $n=76$ modified pieces (with 63 confidently defined as cores, pebble tools, flakes, retouched flakes or flake fragments) (table 7). The sample may be regarded as the background debris of lithic tool assisted activities. In-situ knapping could not, though, be further demonstrated and refits were not identified.

\section{$<<$ Table 7 lithics $>>$}

\section{< Figure 6 illustration of 'short-axes' from Hang Trống 》>}

\section{DISCUSSION}

Distinct patterning within the results of the various proxy analyses permitted separation into four depositional phases: a mixed phase and three largely undisturbed phases of site use. Phases are described from the base of excavation upwards.

\subsection{Phase III}

This phase incorporates material from contexts identified between the current excavation base, dated to 24,244-24,887 cal. BP (UBA-17272), and the appearance of a large shell midden (commencing in Phase II). Data are drawn exclusively from Trench 1 (contexts 8100-8111) (figure 5). Compared to contexts higher in the stratigraphic sequence, sediments at this depth are almost devoid of cyclophorids; however, infrequent freshwater shells, charcoal and small numbers of bone fragments and cultural material was recovered to full depth. Notable amongst the modest vertebrate fauna recovered (table 5) was a complete metapodial from a Manis sp. (pangolin) in context (8111). This piece is slightly damaged on the dorsal distal surface (lateral side) and proximally on the lateral side, preventing clear identification to element. Two species of pangolin are presently found in Vietnam: Manis pentadactyla (Chinese pangolin) in the north and centre of the country, and M. javanica (Sunda pangolin) in the centre and south (Lekagul \& McNeely 1988; Sterling et al. 2006). 
Techno-typological analysis produced a diverse range of pieces, a greater predominance of which was made on limestone $(62.5 \%, n=10 / 16$ - single surface find excluded), including: one core, five flakes, one flake fragment (from section cleaning), one pebble fragment/pebble tool ('short axe') and a burnt limestone pebble fragment. Shale pieces were less common $(25 \% n=4 / 16)$ : two flakes and two pebble fragments ('short-axes'). This phase also yielded the site's only quartzite piece (artefact 17) - a tertiary, retouched flake ('scraper'), and the only piece of sandstone: a flaked pebble fragment. Fourteen modified pieces were also identified during the attribute analysis. These comprised: 1 core, 3 pebble tools, 7 complete flakes, 1 flake fragment 1 one retouched flake.

As this phase broadly covers the LGM it is significant that fragments of Dipterocarpaceae (cf. Dipterocarpus) and Sapotaceae (cf. Manilkara or Palaquium) were found in contexts $(8100,8103 \& 8110, \&$ in 8105) (table 2). The genus Dipterocarpus contains c. 70 species of large $(c .60 \mathrm{~m})$ rainforest trees, with a wide geographic distribution through the tropics (see Ashton 1988). Sapotaceae (cf. Manilkara sp. or Palaquium sp.) is a pantropical family of flowering plants, most species of which produce edible fruit. Pinaceae and two endocarps of Celtis sp. (Family: Ulmaceae) were also recovered. The former ranges from subarctic to tropical environments, including limestone karst (Sterling et al. 2006) and also yields edible seeds. On the basis of the available comparatives, the Hang Trông Celtis sp. specimens are more likely to be $C$. australis L. (Mediterranean hackberry) or less likely the $C$. elim. sinensis Piers (Chinese hackberry). C. australis is a component of more open dry deciduous forest regionally (e.g. Sun et al. 1986).

The $n$-alkane data from this depth in the excavation indicates a vegetation cover that is similar to today (figure 4). The plants around the cave do not seem to have been adversely effected by the climate downturn. Compound-specific isotope analysis of both $n$-alkanoic acid and $n$-alkane higher plant lipids also indicate that the prevailing occurrence of $\mathrm{C}_{3}$ vegetation. Pollen records from the South China Sea during this time indicate herbs and grasses, with some temperate broad leaf plant types dominated most lowland landscapes (Sun et al. 2003). The well-watered and enclosed environment within the Tràng An massif appears to have provided a stable set of conditions for sub-tropical plants despite the climatic downturn.

\subsection{Phase II}

The deposits Phase II span a period of approximately 2000-2500 years: from 17,845-18,520 (UBA-14885) and 18,229-18,708 cal. BP (UBA-14886) to a little before 15,522-16,663 cal. BP (UBA-14884). Macro-vertebrate faunal remains are comparatively rare (NISP $n=57$ ), with indeterminate large mammal fragments making up the bulk of this total (table 5). Deer (Cervidae) are represented only by distal elements (including a burnt phalange and carpal). Cercopithecidae also feature, with notable finds including two mandibular fragments with partial in-situ dentition. The first of these was recovered from near the base of the shell midden in Trench 1 context (8016). Charcoal from this context is dated to 18,229-18,708 cal. $\mathrm{BP}$. The specimen consists of a right $\mathrm{M}_{1}$ with alveoli for $\mathrm{M}_{2}$ and $\mathrm{M}_{3}$ - indicating an adult of five or more years of age (Smith et al. 1994) and is attributable to Macaca cf. mulatta based on biometric data (Swindler 2002, table 112). The second, recovered from Trench 3 context (8312), was from a juvenile: comprising a (left) $\mathrm{dp}_{1}$ in wear a d $\mathrm{d}_{2}$ and an erupting $\mathrm{M}_{1}$ in one fragment, with a similarly faceted $\mathrm{dp}_{2}$ in a second associated fragment (from the right of the mandible). Evidence of other terrestrial-arboreal and arboreal taxa includes: Sciuridae, from mandible fragments equivalent in size to Sciurus sp., Hystricidae by isolated teeth, and one 
avian family, Phasianidae, from a fragment of left coracoid, identified as being from a gallopheasant (Lophura sp.) also recovered from near the base of the shell midden in Trench 1 context (8107). Micro-vertebrate remains are noticeably rare compared to higher in the sequence, where they are linked to cave-roosting birds. Infrequent freshwater crab chelae were also identified.

The lower part of this phase yielded molluscan evidence from four consecutive and approximately equal spits within context (8019) and the highest quantities (MNI) of molluscs in the phase (table 6). Cyclophorids dominated but a number of other taxa were also represented. These too are associated with forested/arboreal environments, such as Amphidromus sp., which lives on trees and shrubs. Three fragments of the freshwater mussel Unio spp. appear at this point, as do fragments of Ellobium aurisjudae. Unionidae generally inhabit freshwater environments, such as slow rivers, lakes or ponds; while Ellobium aurisjudae can inhabit quite a broad range of aquatic environments, from muddy estuaries to mangroves (Nguyen Ngoc Thach 2005). From the top of the phase (contexts 8010 \& 8011) only a low quantity of molluscs were recovered and three species of Cyclophorus. The molluscan data from Phase II, though, supports the picture that the area around the cave was at this time forested and contained a source of freshwater in its vicinity.

Techno-typological analysis indicated that shale was the predominant raw material used in the manufacturing of lithic artefacts 89.6 per cent $(n=26 / 29-$ excluding potentially natural pieces). This included flakes, flake fragments and one pebble fragment ('short axe'). The three remaining pieces were limestone flakes/flake fragments (table 7). Attribute analysis identifications were more conservative: $n=20$, comprising: 1 pebble tool, 9 complete flakes and 10 flake fragments.

Although palynological work was hampered by the degraded state of pollen grains, some identification was nonetheless possible for Phase II, including tree families: Brassicacaeae (Crucifer), Rubiaceae, Leguminosae (Fabaceae/Mimosa), Betulaceae and Pinus or Podocarpus; and more diverse families, such as Moraceae or Urticaceae, which are both mixed families of trees, herbs, climbers or succulents, preferring warm tropical and lowland forest regions; Ulmaceae trees and shrubs persist, and Poaceae, which is an open ground grass taxa also appears. Proximal pollen records from comparable conditions within China reflect the findings from Hang Trống, whereby sub-tropical forests dominate (Wang et al. 2012). Charred fragments of Dipterocarpaceae (cf. Dipterocarpus) were recovered from contexts (8016 \& 8100); as were specimens of Pinaceae and Sapotaceae (context 8100). Fragments of Rhizophoraceae (cf. Rhizophora) tree and shrub taxa came from the top of the phase (context 8010) in Trench 1. These latter are significant components of mangrove forest (Nguyen Ngoc Chinh et al. 1996) though the potential proximity of the site to this habitat at this time has yet to be determined. Leguminosae (cf. Dialium sp.) fragments were identified from this phase in Trench 3, context (8308). Remains of Celtis sp. endocarps are notably increased from Phase III, while those of the nut Canarium spp. (Family: Burseraceae) appear for the first time (table 2). It is unclear if these changes relate to more intensive use of the site during Phase II (see figure 5) or to a shift in (through continuing presence of) forest conditions.

Towards the base of this phase $(141.0 \mathrm{~m}$. asl.) the $n$-alkane data display a slight increase in average chain length. This potentially signals that a resurgent southwest monsoon during the early post-LGM provided a more favourable growing environment; something that may also have been linked to more intensive use of the site. Compoundspecific isotope analysis of both $n$-alkanoic acid and $n$-alkane higher plant lipids remains 
stable through-out the phase, indicating a predominantly $\mathrm{C}_{3}$ vegetation cover, contradictory to evidence from islands further south where $\mathrm{C}_{4}$ plant-type dominate at this time (Wurster et al. 2010). The $n$-alkane data indicate vegetation broadly similar to that seen in the property today.

\subsection{Phase I}

The final intact occupational phase in the excavation is associated with an age 14,056-14,902 cal. BP (UBA-21288) from Trench 3 and 15,522-16,663 cal. BP (UBA-14884) in Trench 1. Representatives from five macro-vertebrate mammalian families were identified: Cervidae, Hystricidae, Mustelidae (Arctonyx collaris), Cercopithidae (cf. Macaca sp.) and Sciuridae. The deer (Cervidae) remains were represented by elements from the distal appendicular skeleton, namely phalanges and a left tarsal. Evidence of porcupines (Hystricidae) comprised of isolated teeth; the vector of introduction for this animal is unclear as porcupines are known to frequent caves in this region (e.g. Bacon et al. 2008). A well preserved right distal humerus belonging to a hog badger (Arctonyx collaris), provides one of the few intact element recoveries from Trench 1. A discrete assemblage of bone fragments from this phase in Trench 3 included pieces of humerus, ulna and femur from a monkey (cf. Macaca sp.), together with a complete femur and burnt mandible from a squirrel (Sciuridae). This concentration of remains - unique on the site - was found within context (8308) (sq. 610/715) and dated 14,056-14,902 cal. BP (UBA-21288). The faunal remains were also found in association with three stone implements, with patches of charcoal and possibly ochre adhering to their surfaces (table 7, artefacts 48 \& 52) and several flakes, all clustered underneath a single whole large freshwater mussel. This context was excavated beneath a large slab of roof fall, which also carried red and black linear pigmentation on its western face: it is as yet unclear if this colouration was deliberately applied or was the result of burning from hearths in the immediate vicinity, though the concentrated nature of these finds certainly bears the hallmarks of having been deliberately placed.

This phase also included low frequencies of micro-vertebrate remains. These were dark in colour (compared to examples from the taphonomic control and mixed contexts above) with calcium carbonate deposition clearly evident. Included among these remains were bones of birds, fish, rodents and shrews. The presence of this material is likely to be an indication that owls were roosting in this part of the cave; though the filtering of microvertebrate bones through the coarse matrix of shells cannot be completely discounted. The bones of insectivorous bats are also present, including Taphozous sp. (tomb bats). These are also interpreted as cave-dwelling fauna and, therefore, almost certainly natural introductions. Small quantities of crab chelae were again found, including burnt specimens. These are more reliably considered to have been introduced to the site by people.

Data from the molluscan column sample from Trench 1 (table 6) that relates to the lower part of this phase includes material from three contexts (8007a-c \& 8009), which is again dominated by Cyclophorous sp., Cryptozona cf. chrysoraphe and Zonitidae cf. Oxychilus sp., present also now is Camaena sp. - an herbivorous terrestrial mollusc that lives in and around shrubs and trees. This taxonomic representation is again indicative of a forested local environment. Single pieces of the aquatic Unio spp. and Cerithrium sp. were also identified; indications that nearby freshwater habitats were being exploited. Burnt shell suggests hearths were set in the middle of the cave. The molluscan sample from the upper part of the this phase (contexts 8006, 8005, 8004, 8003b \& 8003a) was found to be dominated by Cyclophorus sp. Quantities of Cryptozona cf. chrysoraphe and Zonitidae cf. Oxychilus sp. 
were also identified. Camaena sp., which is found deeper in this part of the sequence were not present. This may indicate a shift in local conditions or a change in human gathering patterns.

Techno-typological analysis of the lithic assemblage from the 2010 excavations identified $n=21$ artefacts from Phase I in Trenches 2 and 3 (table 7). This consisted a predominance of shale flakes, flake fragments and blade/flake (with one a burin) specimens; as well as a shale pebble chopper/core ('chopper') and retouched pebble fragment ('shortaxe $\left.^{\prime}\right)-71.4 \%$ per cent ( $n=15 / 21$ - excluding potentially natural pieces) of the total. Other modified pieces were flakes, core and pebble ('pounder'), all of limestone; and a burnt pebble fragment of unknown material. A lower total of artefacts ( $n=17$ modified pieces) was identified through the attribute analysis study, comprising 10 complete flakes, 3 flake fragments, three pebble tools and a core were identified.

The climate is likely to have been variable during this phase: insolation levels were increasing; however the phase is also punctuated by $\mathrm{H} 1$, a noticeably cold-dry period, indicated by sea surface records from the Gulf of Tonkin and the Hulu Cave speleothem record (e.g. Huang 1997; Pelejero et al. 1999; Wang et al. 2001; Visser et al. 2003; Oppo \& Sun 2005; Wei et al. 2007; Shintani et al. 2011). Pollen recovered from within this phase was noticeably degraded, though appears synchronous with a proximal lake pollen record from southern China (Wang et al. 2012). Grains of Brassicacaeae (Crucifer) and Rubiaceae were, also identified, as were pollen grains of Hamamelidaceae, a family formed of tropical trees and shrubs. Betulaceae and Cyperaceae represent other community components from this phase. Dipterocarpaceae were confirmed in the macro-botanical data (table 2). At this time the coastline is thought to have been still up to $500 \mathrm{~km}$ from the Tràng An massif (Yao et al. 2009). Sedimentary facies from coring in the Song Hong Delta (core ND-1, 20.372778 N, 106.146667 E) show that c. 14,900 cal. BP the low-lying landscape beyond the massif contained channels from a meandering river system (Tanabe et al. 2006).

Close to the onset of this phase (141.7 $\mathrm{m}$ asl) $n$-alkane chain lengths are noticeably shorter (average $n$-alkane chain length $\mathrm{C}_{29)}$. It is hypothesized that this reflects the change to colder and dryer conditions in H1. Taken together with increased post-glacial insolation, these factors inhibited production of the protective long-chain $n$-alkanes needed in this subtropical environment; plants only had sufficient resources to maintain shorter $n$-alkanes. Towards the end of the phase, and the expected increase in temperature and moisture, longer $n$-alkane lengths were being produced by the vegetation. Compound-specific isotope analysis of $n$-alkanoic acid and $n$-alkane higher plant lipids from Hang Trống sediments all indicate that the interior of the massif was still characterized by a dominant $\mathrm{C}_{3}$ vegetation signal that was distinct from the environment setting that lay beyond it.

\subsection{Mixed Phase}

Surface contexts (corresponding to approximately the upper-most $10 \mathrm{~cm}$ in each trench) were allocated to a mixed phase due to the likelihood of modern contamination of the sediments. This is borne out through the two radiocarbon dates obtained: $12,594-12,854 \mathrm{cal}$. BP (UBA-09301) from our reconnisance test-pitting here in 2007 and a contrasting date of 32355 cal. BP (UBA-14883) from context (8001) in Trench 1 in 2009. In faunal terms, these contexts are dominated (NISP) by the remains of rodents (Muridae), amphibians (Ranidae: Rana sp.), bird bones (small passerines) and small numbers of fish bones. All are considered most likely to derive from owl pellets from roosting sites in the roof of the cave. Bones of insectivorous bats (Chiroptera) and reptiles (cf. Gekkonidae) likely represent natural deaths 
of cave-dwelling fauna. The bones of larger mammals were rare in this phase, but included a fragment of vertebrae from a non-human primate, possibly relating to historic occasional use of the site by hunters.

Molluscan evidence is relatively diverse, including Clausilia cf. proctostoma - a species that was only otherwise observed during the LGM (see Phase III), which may point to a cooling from within the Pleistocene data of these mixed deposits. Aquatic taxa are present, with Planorbis sp. a species of freshwater snail and a spike in the percentage quantities of Cyclophorus, from c. 65 per cent of the sample to 85 per cent in little more than a couple of centimetres. All of the terrestrial species identified from this phase are known to live in, around or beneath trees, and in the case of other identifications, such as Cryptozona cf. chrysoraphe and Zonitidae cf. Oxychilus sp., they are likely to inhabit very broad environmental spheres that encompass arboreal environments.

Technologically, the upper-most contexts (8200-8203) in Trench 2 and (8300-8302) in Trench 3 produced eight lithics through techno-typological analysis, and eight through attribute analysis. Techno-typologically, the identified pieces included 1 limestone pebble fragment that might have been a core, 3 shale flake fragments, 3 limestone flakes and a limestone pebble flaked fragment ('short axe') (table 7). Attribute analysis of the same sample identified 1 core, 5 complete flakes, 1 pebble tool ('short-axe') and 1 flake fragment.

This phase contains the only substantial concentration $(60 \%)$ of identifiable pollen recovered. This is almost certainly due to modern wind-blown grains becoming trapped within the sediments as erosion and localized micro-re-deposition of these takes place, given the cave's morphology. Charred fragments from samples taken within this phase reveal a number of Dipterocarpaceae specimens; together with Celtis sp. and Canarium spp. fragments (table 2). The climate signal contains both evidence of warm, moist conditions and also indications of sediment accumulating under cooler conditions. n-Alkane biomarkers average high chain lengths, possibly simply a reflection of contemporary sub-tropical conditions.

\section{CONCLUSION}

The results of work conducted at Hang Trống highlight the potential resilience of limestone forest habitats in the northern tropical zone of mainland Southeast Asia. Multiple lines of evidence suggest that these forest formations can sustain themselves through substantial local climatic and environmental change.

Palynological and macro-botanic evidence indicates the persistence of tropical forest cover within Tràng An during the LGM, a period when the surrounding lowlands were characterised by grassland environments. Invertebrate and vertebrate fauna data corroborate the strong arboreal nature of the local habitats within the massif and their durability across this climate downturn. Compound specific analysis of plant biomarkers shows a common $C_{3}$ photosynthetic pathway for local vegetation. The $n$-alkanes recovered from Hang Trống indicate that the most dominant chain length in the modern vegetation $\left(\mathrm{C}_{31}\right)$ is also predominant in the sedimentary record at the site. This is concurrent with other plant zones from this latitude, thus we can be confident that evidence from our analysis of $n$ alkanes reflects, with some clarity, regional climatic conditions. At c. $15 \mathrm{kBP}$ a change in the forest dynamics is indicated by a reduction in $\mathrm{C}_{31} n$-alkane and an increase in $\mathrm{C}_{27} n$-alkane. $\mathrm{A}$ dramatic change in $n$-alkane chain length at $c .15 \mathrm{kBP}$ coincides with the $\mathrm{H} 1$ event. This can be attributed to a strengthening of the northeast monsoon during this interval (e.g. Huang et 
al. 2011). The associated increase in aridity does not, however, appear to have instigated a substantial shift in local vegetation; conceivably in part due to adaptations toward aridity within limestone forest, conditions rebounded and have persisted through the Holocene.

The occupational record from Hang Trống appears to indicate intervals of more and less intensive site-use, peaking in the period immediately after the LGM, but always at a relatively low scale compared, for example to the later midden deposits from elsewhere in the massif, such as Hang Boi (Rabett et al. 2011). The abundance of particularly cyclophorids during the wet southwest monsoon is taken as a likely indicator that this was probably the main season of use, though visits outside of this time cannot be ruled out. There are hints of caching activity that, if correct, are suggestive of provisioning. The nature of this throughcave certainly raises the possibility that it was utilised primarily as a corridor to travel between valleys; the generally equitable conditions providing a useful temporary stopping point.

The technological sample obtained from the 2010 excavation was small ( $n=74$ artefacts), precluding statistically robust statements about observed variability, hence the conclusions we present here are tentative. Patterning in the frequency of artefact categories, form of platform (i.e. cortical, plain, pointed, crushed), flaking direction, striking platform thickness and exterior platform angle) appeared within the lithic assemblage suggests a shift in knapping behaviour and hence potentially mobility between the LGM and the post-LGM (Phan 2014). This shift was from one where limestone predominated, but where a wider range of materials were utilised, during the Phase III (LGM) use of the site, to sourcing that more particularly focused on shale, especially in Phase II. A higher observed frequency of dorsal flake scar counts is also suggestive of greater reduction intensity during the LGM compared to later phases of site-use. The frequency of flakes and flake fragments is considerably lower than is seen during the later phases. Both raise the possibility that occupation of the site during this period involved a change in curation and 'technological organization' (after Nelson 1991), if not in site-use, and may turn out to reflect difference in risk levels and mobility strategies (Phan 2014). As the classes of artefact recovered appear to have been largely consistent through-out, variability was perhaps situated primarily in how technological strategies were implemented rather than in technological forms themselves. In other words: the general reduction strategy (the technology) appears to not have changed, but attribute analysis of our sample suggests that components or steps in that strategy (the technological organization) were altered in response to external pressures.

Pieces resembling Hoabinhian 'short-axes' persisted through all three phases (table 7, artefacts $1,7,10,13,29,46 \& 87)$. Artefact 13 from this list is from a secure context overlying the deepest current date from Hang Trống (c. 24.4 cal. kBP), indicating an age-range for this artefact-type from close to that of the earliest proposed for the Hoabinhian in Vietnam ( $c f$. Yi et al. 2008) up to the top of the sequence. This finding is in-keeping with the technological durability that has been observed elsewhere for the Hoabinhian (e.g. Forestier et al. 2015). The lack of other supposed type-artefacts attributed to the Hoabinhian, most notably 'Sumatraliths' or unifacial discoid pieces, which have been considered definitive elements (e.g. Ha Van Tan 1997; White \& Gorman 2004) also highlights the variable expressions that the Hoabinhian encompasses. In a reversion to the original adaptive emphasis of Gorman (1970, 1971), we consider that the Hoabinhian record might be more aptly described in terms of a technological (and subsistence) 'eco-system' of responses rather than as a singular entity (see also e.g. Nguyen Viet 2000; Nguyen Gia Doi 2005). 
Indications from the current study suggest that foraging groups focused attention on the exploitation of resources available within the Tràng An massif at least on a seasonal basis over a long period of time: many thousands of years. This stability and concentration of resources carries wider implications for our understanding of the archaeology of the region. The consistent recovery of occupational evidence from limestone environments may have significance beyond the better preservation offered by these settings and traditional research focus within them. They may represent genuine 'islands of humanity': points on the landscape that early populations occupied consistently and exploited preferentially over millennia because of the surety they offered in resource access (Rabett et al. 2011), a fact likely tied to their refugial character (see Phoca-Cosmetatou \& Rabett 2014).

The results of our analysis point strongly to the presence of a forested environment within Tràng An thoughout the course of the last twelve thousand years of MIS-2, and provide testament to its resilience in the face of large-scale climate and environmental change. Forest continuity here into the Holocene and present day (see Rabett et al. 2011; Ludgate et al. forthcoming) underscores and extends that resilience. The effects of modern climate change on tropical environments had been seen as secondary to that predicted from deforestation and extractive industry (Sala et al. 2000); however, the projected climate-driven impact on environments and communities in Southeast Asia has grown significantly in the last decade. Coastal and low-lying island habitats and their associated populations are now known to face an acute threat from climate-driven inundation and environmental transformation (Nicholls \& Cazenave 2010; Rietbroek et al. 2016). While the corpus of literature on the impact to coastal habitats globally gathers apace (e.g. Virah-Sawmy et al. 2009; Kirwan et al. 2010; Holland 2012; Mendoza-González et al. 2013; Hunter et al. 2015), with few recent exceptions (e.g. Wetzel et al. 2012; Faridah-Hanum et al. 2014; Latinne et al. 2015) the effect of climate change on coastal tropical terrestrial habitats is still an underrepresented field, and a body of research to which this study contributes. In closing, then we suggest that there are notable implications for conservation arising from the Hang Trống study. Firstly, long-term early human presence in Tràng An, even under conditions when vegetation was more stressed, does not appear to have been adverse to forest survival. That being so, there is an argument to be made that with careful management the impact of modern visitors to this and similar karstic properties on the World Heritage List could be sustainable. Secondly, it is now generally accepted that refugia may offer the best chance for the survival of many taxa under conditions of anthropogenic climate change (e.g. Médail \& Diadema 2009; Ashcroft 2010; Keppel \& Wardell-Johnson 2012; Keppel et al. 2012). The data from Hang Trống, therefore, add additional weight to that contention. In line with other refugial habitats, tropical limestone forests should be considered as a conservation priority. Finally, faced with the prospect of substantial transformation through climate change and regional sea-level rise our findings also give reason for optimism. With diligent management the chances of survival remain positive for these biodiverse, richly endemic and archaeologically bountiful landscapes.

\section{ACKNOWLEDGMENTS}

We would like to thank the Tràng An Management Board, the Ninh Bính Provincial People's Committee and Xuan Truong Enterprise for continuing to recognize the importance of archaeological research within the Tràng An World Heritage property. RR gratefully acknowledges that key funding for much of this work came through the McDonald Institute for Archaeological Research, and via the Evans Fund, Department of Social Anthropology, 
both at University of Cambridge. He also wishes to further thank the McDonald Institute, and the School of Geography, Archaeology and Palaeoecology (including the 14Chrono Centre) at Queen's University, Belfast for their long-term involvement with this project. The authors are very grateful to Patrick Roberts (associate editor) for the opportunity to contribute to this timely and important special issue; and for the constructive comments that he and three anonymous reviewers made on the manuscript.

\section{REFERENCES}

Adam, J.H. \& Mamat, Z. 2005. Floristic composition and structural comparison of limestone forests at three different elevations in Bau, Kuching, Sarawak, Malaysia. Journal of Biological Sciences 5(4): 478-485.

Andrews, P. 1990. Owls, Caves, and Fossils. University of Chicago Press, Chicago.

Ashcroft, M.B. 2010. Identifying refugia from climate change. Journal of Biogeography 37: 1407-1413.

Ashton, P.S. 1988. Dipterocarp biology as a window to the understanding of tropical forest structure. Annual Review of Ecological Systems 19: 347-370.

Bacon, A-M., Demeter, F., Duringer, P., Helm, C., Bano, M., Vu The Long, Nguyen Thi Kim

Thuy, Antoine, P-O., Bui Thi Mai, Nguyen Thi Mai Huong, Dodo, Y., Chabaux, F., Rihs, S. 2008. The Late Pleistocene Duoi U'Oi cave in northern Vietnam: palaeontology, sedimentology, taphonomy and palaeoenvironments. Quaternary Science Reviews 27: $1627-1654$.

Banjoo, D.R. \& Nelson, P.K. 2005. Improved ultrasonic extraction procedure for the determination polycyclic aromatic hydrocarbons in sediments. Journal of Chromatography A 1066: 9-18.

Barker, G. 2013. Rainforest foraging and farming in island Southeast Asia: the archaeology of the Niah Caves, Sarawak. Vol. 1. McDonald Institute Monographs and Sarawak Museums.

Barton, R.N.E., Bouzouggar, A., Collcutt, S.N., Gale, R., Higham, T.F.G., Humphrey, L.T., Parfitt, S., Rhodes, E., Stringer, C.B., Malek, F. 2005. The Late Upper Palaeolithic occupation of the Moroccan northwest Maghreb during the Last Glacial Maximum. African Archaeological Review 22(2): 77-100.

Birks, H.J.B., 1981. The use of pollen analysis in the reconstruction of past climates: a review. Climate and History, 11: 137.

Birks, H.J.B. \& Birks, H.H. 1980. Quaternary Palaeoecology. Edward Arnold, London.

Blyth, A.J., Asrat, A., Baker, A., Gulliver, P., Leng, M.J., Genty, D. 2007. A new approach to detecting vegetation and land-use change using high-resolution lipid biomarker records in stalagmites. Quaternary Research 68(3): 314-324.

Brown, P., Sutikna, T., Morwood, M.J., Soejono, R.P., Jabniko, Wayhu Saptomo, E. Rokus Awe Due. 2004. A new small-bodied hominin from the Late Pleistocene of Flores, Indonesia. Nature 431: 1055-1091.

Carlos, A.J.B. 2010. Inferring Subsistence Patterns in the Ille Cave and Rockshelter Site: The Macrobotanical Evidence. MS Thesis. University of the Philippines

Ceron, J. n.d. Report on archaeological wood collected from Tràng An cave sites. Unpublished project report.

Chang, C-P., Wang, Z., McBride, J., Liu, C-H. 2005. Annual cycle of Southeast Asia-maritime continent rainfall and the asymmetric monsoon transition. Journal of Climate 18(2): 287301. 
Clark, P.U., Dyke, A.S., Shakun, J.D., Carlson, A.E., Clark, J., Wohlfarth, B., Mitrovica, J.X., Hostetler, S.W., McCabe, A.M. 2009. The Last Glacial Maximum. Science 325: 710-714.

Clements, R., Sodhi, N.S., Schilthuizen, M., Ng, P.K.L. 2006. Limestone karsts of Southeast Asia: imperiled arks of biodiversity. BioScience 56(9): 733-742.

Clements, R., Nga, P.K.L., Lub, X.X., Ambu, S., Schilthuizen, M., Bradshaw, C.J.A. 2008. Using biogeographical patterns of endemic land snails to improve conservation planning for limestone karsts. Biological Conservation 141: 2751-2764.

Cook, E.J. 2009. A record of late Quaternary environments at lunette-lakes Bolac and Turangmoroke, Western Victoria, Australia, based on pollen and a range of non-pollen palynomorphs. Review of Palaeobotany and Palynology 153: 185-224.

Do Cong Thung. 2014. Distinctive Features of the Property of Cat Ba Archipelago, Vietnam. Journal of Earth Science and Engineering 4: 271-283.

Eglinton G. \& Hamilton, R.J. 1967. Leaf Epicuticular Waxes. Science 156: 1322-1335.

Ella, A.B., Meniado, J.M., Escobin, R.P., Maruzzo, M.M., America, W.M. 2009. Anatomical Identification Handbook of Philippines Dipterocarps.FPRDI-DOST College, Laguna.

Fægri, K. \& Iversen, J. 1989. Textbook of pollen analysis. $4^{\text {th }}$ edition. John Wiley \& Sons, Chichester.

Faridah-Hanum, I., Latiff, A., Khalid Rehman Hakeem, Ozturk, M. 2014. Mangrove Ecosystems of Asia: Status, Challenges and Management Strategies. Springer: New York.

Forestier, H., Zeitoun, V., Winayalai, C., Métais, C. 2013. The open-air site of Huai Hin Northwestern Thailand): chronological perspectives for the Hoabinhian. C. R. Palevol 12: 45-55.

Forestier, H., Sophady, H., Puaud, S., Celiberti, V., Frère, S., Zeitoun, V., Mourer-Chauviré, C., Mourer, R., Heng Than, Billault, L. 2015. The Hoabinhian fromLaang Spean Cave in its stratigraphic, chronological, typo-technological and environmental context (Cambodia, Battambang province). Journal of Archaeological Science: Reports 3: 194-206.

Furey, N.M., Mackie, I.J., Racey, P.A. 2010. Bat diversity in Vietnamese limestone karst areas and the implications of forest degradation. Biodiversity Conservation 19: 1821-1838.

Gao, Y., Ai, B., Kong, H., Kang, M., Huang, H. 2015. Geographical pattern of isolation and diversification in karst habitat islands: a case study in the Primulina eburnea complex. Journal of Biogeography 42: 2131-2144.

Gorman, C.F. 1970. Excavations at Spirit Cave, Northern Thailand. Asian Perspectives 13: 79107.

Gorman, C.F. 1971. The Hoabinhian and after: subsistence patterns in Southeast Asia during the Late Pleistocene and early Recent periods. World Archaeology 2(3): 300-320.

Hadley, N.F. 1980. Surface Waxes and Integumentary Permeability: Lipids deposited on or associated with the surface of terrestrial plants and animals help protect them from a lethal rate of desiccation. American Scientist 68(5): 546-553.

Hanebuth, T., Stattegger, K., Grootes, P.M. 2000. Rapid flooding of the Sunda Shelf: a lateglacial sea-level record. Science 288:1033-1035.

Hanebuth, T.J.J., Stattegger, K., Bojanowski, A. 2009. Termination of the Last Glacial maximum sea-level lowstand: the Sunda-Shelf data revisited. Global and Planetary Change 66: 76-84.

Ha Van Tan 1997. The Hoabinhian and before. Bulletin of the Indo-Pacific Prehistory Association 16(3): 35-41.

Holland, S.M. 2012. Sea level change and the area of shallow-marine habitat: implications for marine biodiversity. Paleobiology 38(2): 205-217. 
Huang, C.Y., Liew, P.M., Zhao, M., Chang, T.C., Kuo, C.M., Chen, M.T., Wang, C.H., Zheng, L.F., 1997. Deep sea and lake records of the Southeast Asian paleomonsoons for the last 25 thousand years. Earth and Planetary Science Letters 146(1): 59-72.

Huang, E., Tian, J., Steinke, S. 2011. Millennial-scale dynamics of the winter cold tongue in the southern South China Sea over the past $26 \mathrm{ka}$ and the East Asian winter monsoon. Quaternary Research 75: 196-204.

Huang, X., Cui, J., Pu, Y., Huang, J., Blyth, A.J. 2008. Identifying "free" and "bound" lipid fractions in stalagmite samples: An example from Heshang Cave, Southern China. Applied Geochemistry 23(9): 2589-2595.

Hunt, C.O. \& Gilbertson, D.D. 2014. Shorelines, mangroves and human environments in the coastal lowlands of northeastern Borneo during the Late Quaternary. Living in the Landscape. Boyle, K., Rabett, R. \& Hunt, C. (eds.) (McDonald Institute Monographs) Cambridge: McDonald Institute for Archaeological Research, p. 121-136.

Hunter, E.A., Nibbelink, N.P., Alexander, C.R., Barrett, K., Mengak, L.F., Guy, R.K., Moore, C.T., Cooper, R.J. 2015. Coastal vertebrate exposure to predicted habitat changes due to sea level rise. Environmental Management 56: 1528-1537.

Husemann, M., Schmitt, T., Zachos, F.E., Ulrich, W., Habel, J.C. 2014. Palaearctic biogeography revisited: evidence for the existence of a North African refugium for Western Palaearctic biota. Journal of Biogeography 41(1): 81-94.

Intergovernmental Panel on Climate Change (IPCC) 2007-II. Impacts, Adaptations and Vulnerability. Special report. Cambridge University Press: Cambridge.

Ji, X., Kuman, K., Clarke, R.J., Forestier, H., Li, Y., Ma, J., Qiu, K., Li, H., Wu, Y. in press. The oldest Hoabinhian technocomplex in Asia (43.5 ka) at Xiaodong rockshelter, Yunnan Province, southwest China. Quaternary International. DOI:10.1016/j.quaint.2015.09.080.

Keppel, G. \& Wardell-Johnson, G.W. 2012. Refugia: keys to climate change management. Global Change Biology 18: 2389-2391.

Keppel, G., Van Niel, K.P., Wardell-Johnson, G.W., Yates, C.J., Byrne, M., Mucina, L., Schut, A.G.T., Hopper, S.D., Franklin, S.E. 2012. Refugia: identifying and understanding safe havens for biodiversity under climate change. Global Ecology \& Biogeography 21: 393404.

Kienast, M., Hanebuth, T.J.J., Pelejero, C., Steinke, S. 2003. Synchroneity of meltwater pulse 1a and the Bølling warming: new evidence from the South China Sea. Geology 31(1): 6770.

Kirwan, M.L., Guntenspergen, G.R., D’Alpaos, A., Morris, J.T., Mudd, S.M., Temmerman, S. 2010. Limits on the adaptability of coastal marshes to rising sea level. Geophysical Research Letters 37: L23401.

Koch, K. \& Ensikat, H. 2008. The hydrophobic coatings of plant surfaces: epicuticular wax crystals and their morphologies, crystallinity and molecular self-assembly. Micron, 39(7): 759-772.

Kohn, M.J. and Cerling, T.E. 2002. Stable isotope compositions of biological apatite. Reviews in mineralogy and geochemistry, 48(1): 455-488.

Kopp, R.E. 2012. Palaeoclimate: Tahitian record suggests Antarctic collapse. Nature 483: 54950.

Kosma, D.K., Bourdenx, B., Bernard, A., Parsons, E.P., LÜ, S., Joubès, J., Jenks, M.A. 2009. The impact of water deficiency on leaf cuticle lipids of Arabidopsis. Plant Physiology, 151(4): 1918-1929. 
Latinne, A., Meynard, C.N., Herbreteau, V., Waengsothorn, S., Morand, S., Michaux, J.R. 2015. Influence of past and future climate changes on the distribution of three Southeast Asian murine rodents. Journal of Biogeography 42: 1714-1726.

Lekagul, B. and McNeely, J.A. 1988. Mammals of Thailand. Association for the Conservation of Wildlife, Darnsutha Press, Bangkok.

Li, Z., Saito, Y., Matsumoto, E., Wang, Y., Haruyama, S., Hori, K., Le Quoc Doanh, 2006a. Palynological record of climate change during the last deglaciation from the Song Hong (Red River) delta, Vietnam. Palaeogeography, Palaeoclimatology, Palaeoecology 235: 406-430.

Li, Z., Saito, Y., Matsumoto, E., Wang, Y., Tanabe, S., Vu, Q.L. 2006b. Climate change and human impact on the Song Hong (Red River) Delta, Vietnam, during the Holocene. Quaternary International 144: 4-28.

Lockheart, M.J., Van Bergen, P.F., Evershed, R.P. 1997. Variations in the stable carbon isotope compositions of individual lipids from the leaves of modern angiosperms: implications for the study of higher land plant-derived sedimentary organic matter. Organic Geochemistry, 26(1-2): 137-153.

Ludgate, N.F. 2013. Biogenic matter preserved in cave sediments: a new environmental proxy? Unpublished PhD dissertation, Open University.

Ludgate, N.F., Blyth, A.J. Gilmore, I., Gilmour, M. Forthcoming. Leaf wax biomarkers and their use in reconstructing Pleistocene environment from Trang An; an area of archaeological cave investigations from Northern Vietnam.

Marwick, B. \& Gagan, M.K. 2011. Late Pleistocene monsoon variability in northwest Thailand: an oxygen isotope sequence from the bivalve Margaritanopsis laosensis excavated in Mae Hong Son province. Quaternary Science Reviews 30: 3088-3098.

Marwick, B. 2013. Multiple Optima in Hoabinhian flaked stone artefact palaeoeconomics and palaeoecology at two archaeological sites in Northwest Thailand. Journal of Anthropological Archaeology 32: 553-564.

Matthews, J.M. 1966. A review of the 'Hoabinhian in Indo-China'. Asian Perspectives 9: 86-95.

Médail, F. \& Diadema, K. 2009. Glacial refugia influence plant diversity patterns in the Mediterranean basin. Journal of Biogeography 36, 1333-45.

Mendoza-González, G. * , Martínez, M.L., Rojas-Soto, O.R., Vázquez, G., Gallego-Fernández, J.B. 2013. Ecological niche modeling of coastal dune plants and future potential distribution in response to climate change and sea level rise. Global Change Biology 19: 2524-2535.

Meyers, P.A. \& Ishiwatari, R. 1993. Lacustrine organic geochemistry-an overview of indicators of organic matter sources and diagenesis in lake sediments. Organic Geochemistry 20(7): 867-900.

Mijares, A.S., Détroit, F., Piper, P., Grün, R., Bellwood, P., Aubert, M., Champion, G., Cuevas, N., DeLeon, A., Dizon, E. 2010. New evidence for a 67,000-year-old human presence at Callao Cave, Luzon, Philippines. Journal of Human Evolution 59(1): 123-132

Molengraaff, G.A.F. \& Weber, M. 1921. On the relation between the pleistocene glacial period and the origin of the Sunda sea (Java and South China-sea), and its influence on the distribution of coral reefs and on the land- and freshwater fauna, Netherlands Academy of Arts and Sciences (KNAW) Proceedings 23(1): 395-439.

Nelson, M.C. 1991. The Study of Technological Organization. Archaeological Method and Theory 3: 57-100. 
Nguyen Gia Doi 2005. Results of recent research into the lithic industries from Late Pleistocene/ Early Holocene sites in northern Vietnam. Bulletin of the Indo-Pacific Prehistory Association 25(3): 95-97.

Nguyen Ngoc Chinh, Cao Thuy Chung, Vu Van Can., Xuan Dung Nguyen, Vu Van Dung, Nguyen Kim Dao, Tran Hop, Tran, Tuyet Oanh, Nguyen Boi Quynh, Nguyen Nghia Thin, 1996. Vietnam Forest Trees. Agricultural Publishing House: Hanoi.

Nguyen Ngoc Thach, 2005. Shells of Vietnam. Conch Books, Hackenheim.

Nguyen Tu, T.T., Egasse, C., Zeller, B., Bardoux, G., Biron, P., Ponge, J., David, B., Derenne, S. 2011. Early degradation of plant alkanes in soils: A litterbag experiment using ${ }^{13} \mathrm{C}-$ labelled leaves. Soil Biology and Biochemistry, 43(11): 2222-2228.

Nguyen Viet 2000. Homeland of the Hoabinhan in Vietnam. Paper presented at the Association of Southeast Asian Archaeologists in Europe, Sarteano, Italy.

Nicholls, R.J. \& Cazenave, A. 2010. Sea-level rise and its impact on coastal zones. Science 328: 1517-1520.

O'Leary, M.H. 1981. Carbon isotope fractionation in plants. Phytochemistry, 20(4): 553-567.

Oppo, D.W. \& Sun, Y. 2005. Amplitude and timing of sea-surface temperature change in the northern South China Sea: Dynamic link to the East Asian monsoon. Geology 33(10): 785-788.

Osborne, C.P. \& Sack, L. 2012. Evolution of C4 plants: a new hypothesis for an interaction of $\mathrm{CO}^{2}$ and water relations mediated by plant hydraulics. Philosophical Transactions of the Royal Society (B), 367(1588): 583-600.

Paillard, D., Labeyrie, L., Yiou, P. 1996. Macintosh program performs time-series analysis, Eos Trans. AGU, 77: 379 . http://www.agu.org/eos_elec/96097e.html: AGU.

Pala, M., Olivieri, A., Achilli, A. et al. 2012. Mitochondrial DNA signals of Late Glacial recolonization of Europe from Near Eastern refugia. The American Journal of Human Genetics 90: 915-924.

Partin, J.W., Cobb, K.M., Adkins, J.F., Clark, B., Fernandez, D.P. 2007. Millennial-scale trends in west Pacific warm pool hydrology since the Last Glacial Maximum. Nature 449: 453455 .

Partin, J.W., Quinn, T.M., Shen C.-C., Okumura, Y., Cardenas, M.B., Siringan, F.P., Banner, J.L., Lin, K., Hu, H.-M., Taylor, F.W. 2015. Gradual onset and recovery of the Younger Dryas abrupt climate event in the tropics. Nature Communications 6: 8061 (DOI: 10.1038/ncomms9061).

Paz, V.J. 2001. Archaeobotany and Cultural Transformation: Patterns of Early Plant Utilization in Northern Wallacea, Ph.D dissertation, University of Cambridge.

Pelejero, C., Grimalt, J.O., Heilig, S., Kienast, M., Wang, L., 1999. High-resolution UK ${ }_{37}$ temperature reconstructions in the South China Sea over the past $220 \mathrm{kyr}$. Palaeogeography, Palaeoclimatology, Palaeoecology 14(2), 224-231.

Phan, L. 2014. Late Pleistocene lithic technology at Hang Trông cave, Vietnam: climate change and Hoabinhian lithic organization. Unpublished MPhil dissertation, University of Cambridge.

Phoca-Cosmetatou, N. \& Rabett, R. Pleistocene island occupation in the Mediterranean: insights from a tied-biome approach to glacial refugia. Living in the Landscape. Boyle, K., Rabett, R. \& Hunt, C. (eds.). Cambridge: McDonald Institute for Archaeological Research, pp. 83-108. 
Proffitt, T. \& de la Torre, I. 2014. The effect of raw material on inter-analyst variation and analyst accuracy for lithic analysis: a case study from Olduvai Gorge. Journal of Archaeological Science 45: 270-283.

Quade, J., Cerling, T.E., Bowman, J.R. 1989. Development of Asian monsoon revealed by marked ecological shift during the latest Miocene in northern Pakistan. Nature 342: 163-166.

Rabett, R.J. 2013. The early human occupation of Tràng An, Vietnam: archaeological and palaeo-environmental evidence. (Vietnam) Journal of Geology, Series B 336: 1-7.

Rabett, R.J. 2012. Human Adaptation in the Asian Palaeolithic: Hominin Dispersal and Behaviour during the Late Quaternary. Cambridge University Press: Cambridge.

Rabett, R., Appleby, J., Blyth, A., Farr, L., Gallou, A., Giffiths, T., Hawkes, J., Marcus, D., Marlow, L., Morley, M., Nguyên Cao Tân, Nguyên Van Son, Penkman, K., Reynolds, T., Stimpson, S., Szabó, K. 2011. Inland shell midden site-formation: investigation into a late Pleistocene to early Holocene midden from Tràng An, northern Vietnam, Quaternary International 239: 153-169.

Rasmussen, S.O., Seierstad, I.K., Andersen, K.K., Bigler, M., Dahl-Jensen, D., Johnsen, S.J. 2006. Greenland Ice Core Calcium and Oxygen Isotope Data . Data Contribution Series \# 2006-120. NOAA/NCDC Paleoclimatology Program, Boulder CO, USA: IGBP PAGES/World Data Center for Paleoclimatology.

Reimer, P.J., Baillie, M.G., Bard, E., Bayliss, A., Beck, J.W., Blackwell, P.G., Ramsey, C.B., Buck, C.E., Burr, G.S., Edwards, R.L., Friedrich, M., Grootes, P.M., Guilderson, T.P., Hajdas, I., Heaton, T.J., Hogg, A.G., Hughen, K.A., Kaiser, K.F., Kromer, B., McCormac, F.G., Manning, S.W., Reimer, R.W., Richards, D.A., Southon, J.R., Talamo, S., Turney, C.S.M., van der Plicht, J., Weyhenmeyer, C.E. 2009. IntCal09 and Marine09 radiocarbon age calibration curves, 0-50,000 years cal. BP. Radiocarbon 51(4): 1111-1150.

Reynolds, T.E.G. 1989. Techno-typology in Thailand: a case study of the Tham Khao Khi Chan. Indo-Pacific Prehistoric Association 9: 33-43.

Reynolds, T.E.G. 1990. The Hoabinhian: a review. Barnes, G.L. (ed.) Bibliographic Review of Far Eastern Archaeology, Oxbow Books: Oxford, pp. 1-30.

Rietbroek, R., Brunnabend, S-E., Kusche, J., Schröter, J., Dahl, C. 2016. Revisiting the contemporary sea-level budget on global and regional scales. PNAS (Early edition) doi/10.1073/pnas.1519132113

Roberts, P. \& Petraglia, M.D. 2015. Pleistocene rainforests: barriers or attractive environments for early human foragers? World Archaeology. DOI: 10.1080/00438243.2015.1073119

Rommerskirchen, F., Eglinton, G., Dupont, L., Günter, U., Wenzel, C., Rullkötter, J. 2003. A north to south transect of Holocene southeast Atlantic continental margin sediments: Relationship between aerosol transport and compound- specific $\delta 13 \mathrm{C}$ land plant biomarker and pollen records. Geochemistry Geophysics Geosystems 4(12): 1101.

Rose, J.I., Černý, V., Bayoumi, R. 2013. Tabula rasa or refugia? Using genetic data to assess the peopling of Arabia. Arabian Archaeology and Epigraphy 24: 95-101.

Sala, O.E., Chapin III, F.S., Armesto, J.J. et al. 2000. Global Biodiversity Scenarios for the Year 2100. Science 287: 1770-1774.

Sathiamurthy, E. \& Voris, H.K. 2006. Maps of Holocene sea level transgression and submerged lakes on the Sunda Shelf. The Natural History Journal of Chulalongkorn University (Supplement) 2: 1-44. 
Schimanski, A. \& Stattegger, K. 2005. Deglacial and Holocene evolution of the Vietnam shelf: stratigraphy, sediments and sea-level change. Marine Geology 214: 365-387.

Schwark, L., Zink, K., Lechterbeck, J. 2002. Reconstruction of postglacial to early Holocene vegetation history in terrestrial Central Europe via cuticular lipid biomarkers and pollen records from lake sediments. Geology, 30(5): 463.

Shintani, T., Yamamoto, M., Chen, M. 2011. Paleoenvironmental changes in the northern South China Sea over the past 28,000 years: A study of TEX86 derived sea surface temperatures and terrestrial biomarkers. Journal of Asian Earth Sciences 40(6): 1221-1229.

Shoocongdej, R. 1996. Forager Mobility Organization in Seasonal Tropical Environments: A View from Lang Kamnan Cave, Western Thailand, Unpublished Ph.D. dissertation, Department of Anthropology, University of Michigan.

Smith, B.H., Crummett, T.L., Brandt, K.L. 1994. Ages of eruption of primate teeth: a compendium for aging individuals and comparing life histories. Yearbook of Physical Anthropology 37: 177-231.

Soares, P., Trejaut, J. A., Jun-Hun Loo, Hill, C., Mormina, M., Lee, C-L., Chen, Y-M., Hudjashov, G., Forster, P., Macaulay, V., Bulbeck, D., Oppenheimer, S., Lin, M., Richards, M. B. 2008. Climate Change and Postglacial Human Dispersals in Southeast Asia. Molecular Biology Evolution 25(6): 1209-1218.

Sodhi, N.S., Brook, B.W., Bradshaw, C.J.A. 2007. Tropical Conservation Biology. Blackwell Publishing: Oxford.

Stahl, P.W. 1996. The recovery and interpretation of micro-vertebrate bone assemblages from archaeological contexts. Journal of Archaeological Method and Theory 3: 31-75.

Sterling, E.J., Hurley, M.M., Le Duc Minh. 2006. Vietnam: A Natural History. Yale University Press: New Haven and London.

Stimpson, C. M. 2012. Local-scale, proxy evidence for the presence of closed-canopy forest in Northwestern Borneo in the Late Pleistocene: bones of Strategy I bats from the archaeological deposits of the Great Cave of Niah, Sarawak. Palaeogeography, Palaeoclimatology, Palaeoecology 331-332: 136-149.

Sun, X., Wu, Y., Qiao, Y., Walker, D. 1986. Late Pleistocene and Holocene vegetation history at Kunming, Yunnan Province, southwest China. Journal of Biogeography 13(5): 441-476.

Sun, X., Li, X. 1999. A pollen record of the last $37 \mathrm{ka}$ in deep sea core 17940 from the northern slope of the South China Sea. Marine Geology 156: 227-244.

Sun, X., Li, X., Luo, Y.,Chen, X., 2000. The vegetation and climate at the last glaciation on the emerged continental shelf of the South China Sea. Palaeogeography, Palaeoclimatology, Palaeoecology 160: 301-16.

Sun, X., Luo, Y., Fei, H., Tian, J., Wang, P., 2003. Deep-sea pollen from the South China Sea: Pleistocene indicators of East Asian monsoon. Marine Geology 201: 97-118.

Swindler, D.R. 2002. Primate Dentition: An Introduction to the Teeth of Non-Human Primates. Cambridge University Press, Cambridge.

Tanabe, S., Saito, Y., Vu, Q.L., Hanebuth, T. J.J., Kitamura, A., Ngo, Q.T. 2006.Holocene evolution of the Song Hong (Red River) delta system, northern Vietnam. Sedimentary Geology 187: 29-61.

Thompson G.B. 1996.The Excavation of Khok Phanom Di, a Prehistoric Site in Central Thailand. Volume IV: Subsistence and Environment: The Botanical Evidence (The Biological Remains, Part II). The Society of Antiquaries of London, London.

Tostevin, G.B. 2013. Seeing Lithics: A Middle Range Theory for Testing for Cultural Transmission in the Pleistocene. Oxbow Books: Oxford. 
Van Bergen, P.F., Bull, I. D., Poulton, P.R., Evershed, R.P. 1997. Organic geochemical studies of soils from the Rothamsted classical experiments - I. Total lipid extracts, solvent insoluble residues and humic acids from broadbalk wilderness. Organic Geochemistry, 26: 117-135.

van den Bergh, G.D., Meijer, H.J.M., Rokus Awe Due, Morwood, M.J., Szabó, K., van den Hoek Ostende, L.W., Sutikna, T., Saptomo, E.W., Piper, P.J., Dobney, K.M. 2009. The Liang Bua faunal remains: a 95 kyr. sequence from Flores, East Indonesia. Journal of Human Evolution 57(5): 527-537.

Verleyen, E., Hodgson, D.A., Milne, G.A., Sabbe, K., Vyverman, W. 2005. Relative sea-level history from the Lambert Glacier region, East Antarctica, and its relation to deglaciation and Holocene glacier readvance. Quaternary Research 63: 45-52.

Virah-Sawmy, M., Willis, K.J., Gillson, L. 2009. Threshold response of Madagascar's littoral forest to sea-level rise. Global Ecology and Biogeography 18: 98-110.

Visser, K., Thunell, R., Stott, L. 2003. Magnitude and timing of temperature change in the Indo-Pacific warm pool during deglaciation. Nature 421(6919): 152- 155.

Wang, C. \& Enfield, D.B. 2001. The tropical Western Hemisphere warm pool. Geophysical Research Letters 28(8): 1635-1638.

Wang, S., Lu, H., Han, J., Chu, G., Liu, J. and Negendank, J.F. 2012. Palaeovegetation and palaeoclimate in low-latitude southern China during the Last Glacial Maximum. Quaternary International, 248: 79-85.

Wang, P., Zhang, Q., Wang, Y., Wang, T., LI, X., Ding, L., Jiang, G. 2010. Evaluation of Soxhlet extraction, accelerated solvent extraction and microwave-assisted extraction for the determination of polychlorinated biphenyls and polybrominated diphenyl ethers in soil and fish samples. Analytica Chimica Acta 663(1): 43-48.

Wang, Y.J., Cheng, H., Edwards, R.L., An, Z.S., Wu, J.Y., Shen, C.C., Dorale, J.A. 2001. A high-resolution absolute-dated late Pleistocene monsoon record from Hulu Cave, China. Science 294: 2345-2348.

Wei, G., Deng, W., Liu, Y., Li, X. 2007. High-resolution sea surface temperature records derived from foraminiferal $\mathrm{Mg} / \mathrm{Ca}$ ratios during the last $260 \mathrm{ka}$ in the northern South China Sea. Palaeogeography, Palaeoclimatology, Palaeoecology 250(1): 126-138.

Wetzel, F.T., Kissling, W.D., Beissmann, H., Penn, D.J. 2012. Future climate change driven sea-level rise: secondary consequences from human displacement for island biodiversity. Global Change Biology 18: 2707-2719.

Weyhenmeyer, C.E., Burns, S.J., Waber, H.N., Aeschbach-Hertig, W., Kipfer, R., Loosli, H.H., Matter, A. 2000. Cool glacial temperatures and changes in moisture source recorded in Oman ground waters. Science 287: 842-845.

White, J.C. \& Gorman, C.F. 2004. Pattern in 'amorphous' industries: the Hoabinhian viewed through a lithic reduction sequence. Paz, V. (ed.) Southeast Asian Archaeology: Wilhem G. Solheim II Festschrift. University of the Philippines Press: Manilla, pp. 411-443.

Williams, A.N., Ulm, S., Cook, A.R., Langley, M.C., Collard, M. 2013. Human refugia in Australia during the Last Glacial Maximum and Terminal Pleistocene: a geospatial analysis of the 25-12 ka Australian archaeological record. Journal of Archaeological Science 40: 4612-25.

Wurster, C.M., Bird, M.I., Bull, I.D., Creed, F., Bryant, C., Dungait, J.A., Paz, V. 2010. Forest contraction in north equatorial Southeast Asia during the Last Glacial Period. PNAS. 107(35): 15508-15511. 
Yao, Y.T., Harff, J., Meyer, M., Zhan, W.H. 2009. Reconstruction of paleocoastlines for the northwestern South China Sea since the Last Glacial Maximum. Science in China Series D: Earth Sciences 52(8): 1127-1136.

Yi, S., Lee, J-J., Kim, S., Yoo, Y., Kim, D. 2008. New data on the Hoabinhian: investigations at Hang Cho cave, northern Vietnam. Bulletin of the Indo-Pacific Prehistory Association 28: 73-79.

Zukswert, H. 2014. Characterisation of an owl pellet assemblage from Hang Tr6ng, Vietnam: a study of taphonomy and taxonomy. Unpublished MPhil Dissertation in Archaeological Science, University of Cambridge. 


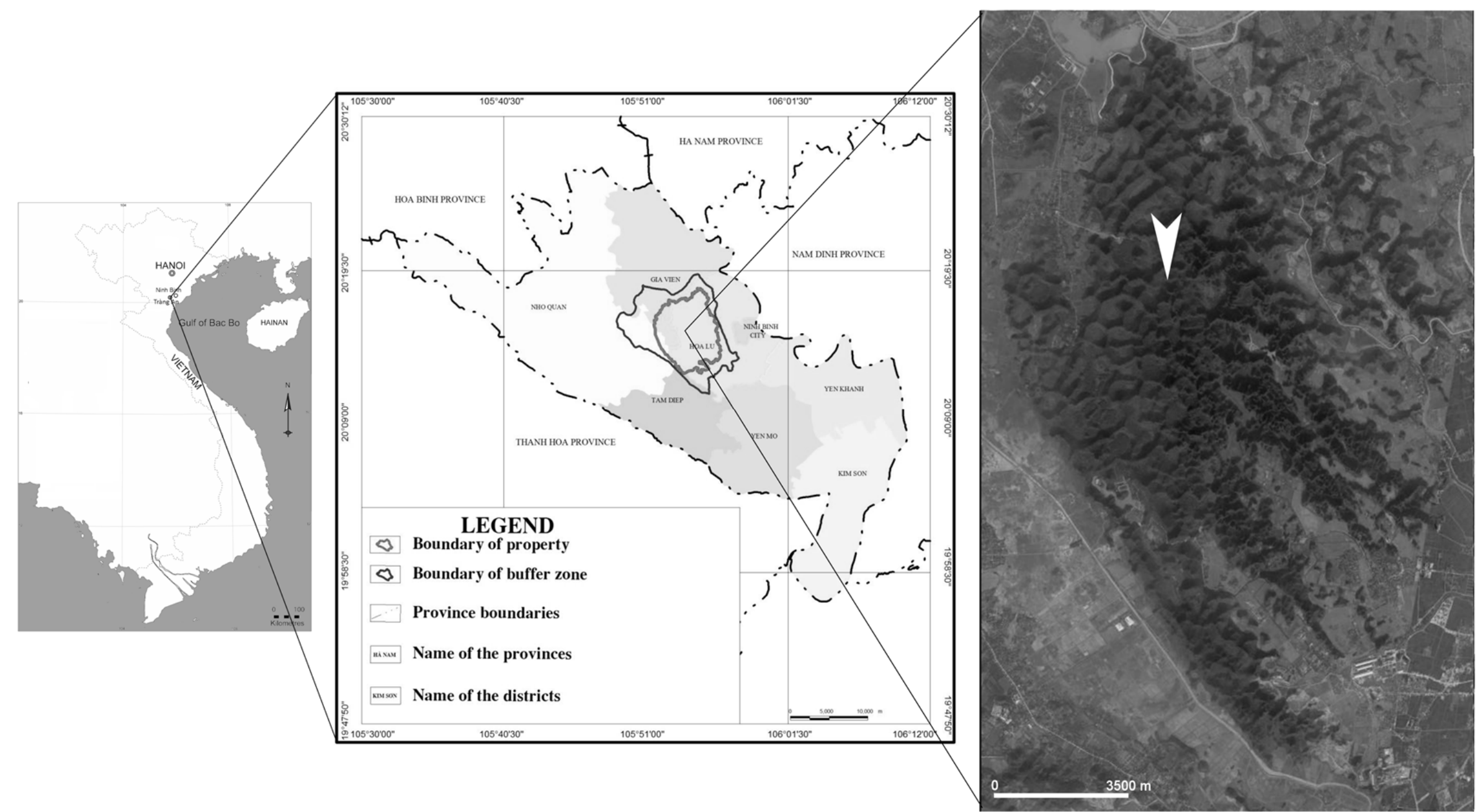

« Figure 1, the location of Tràng An, Ninh Binh province; the World Heritage Site core and buffer zone boundaries of the property; and the location of Hang Trống within the Tràng An limestone massif (right-hand image: Google Earth). >> 

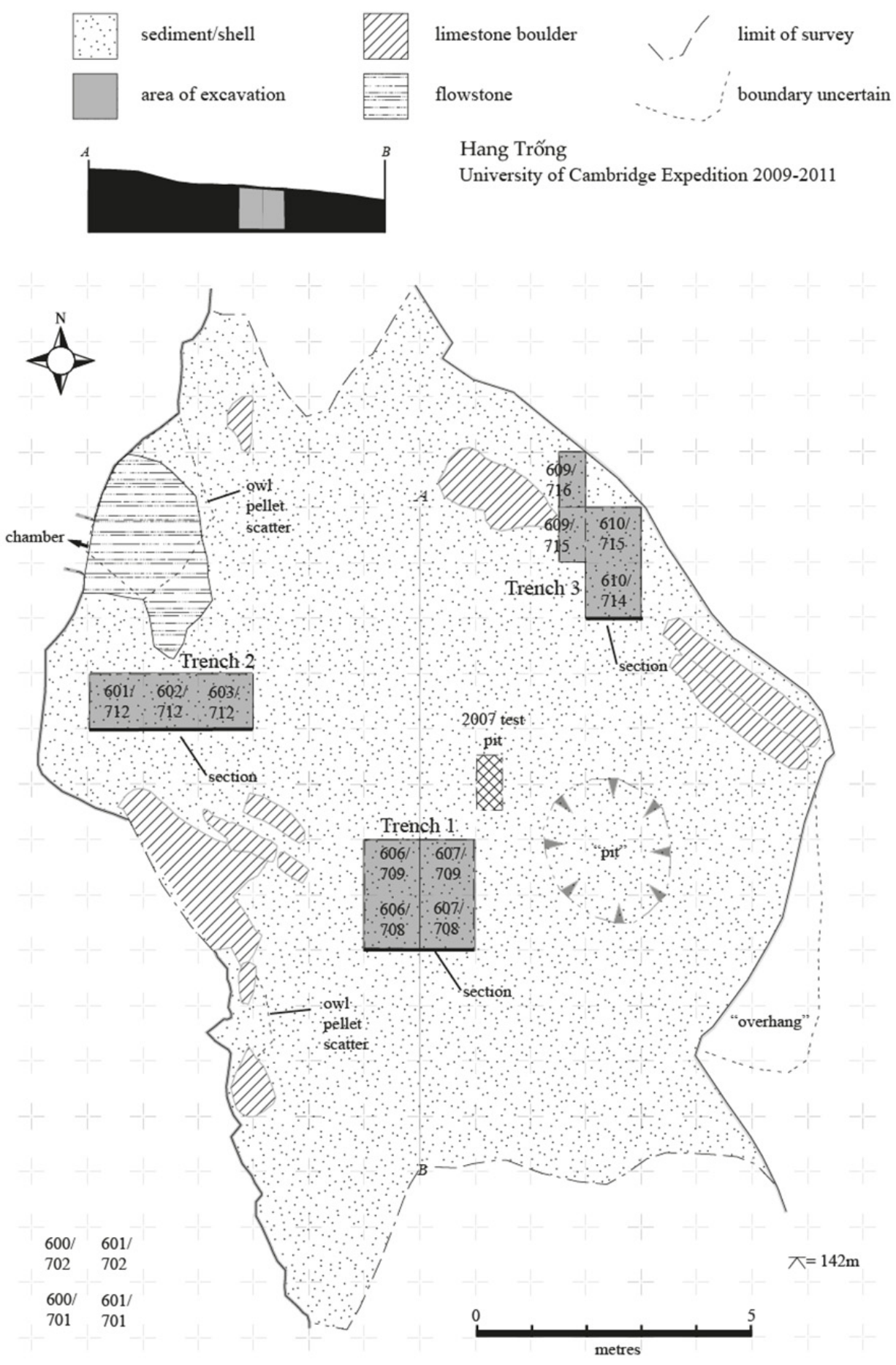

< Figure 2, plan of Hang Trống showing pertinent site features, including geoarchaeological sampling points, the locations of the 2007 test pit and of TR1-3. Survey: J. Hawkes, C. Stimpson \& M. Verhoeven. Drawing: C. Stimpson. >> 


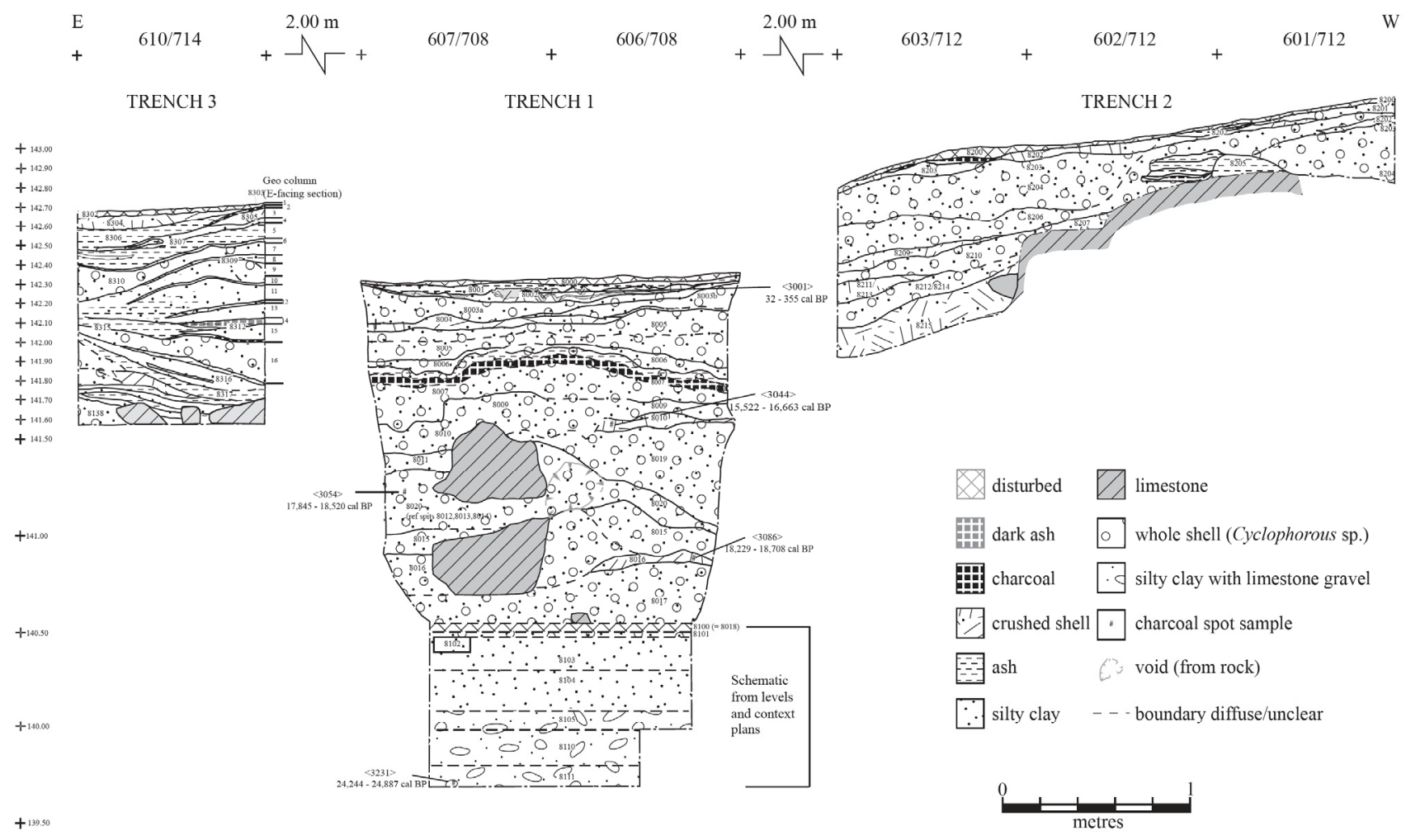

$\ll$ Figure 3, composite of the north-facing sections from Trenches 1-3 across Hang Trống. East-West distance between trenches has been fore-shortened for the purpose of this illustration. Original drawings: Borbala Nyiri, Lucy Farr, Mike Morley, Jason Hawkes, Marc Verhoeven, David Simpson and Jo Appleby; composition: C. Stimpson. >> 


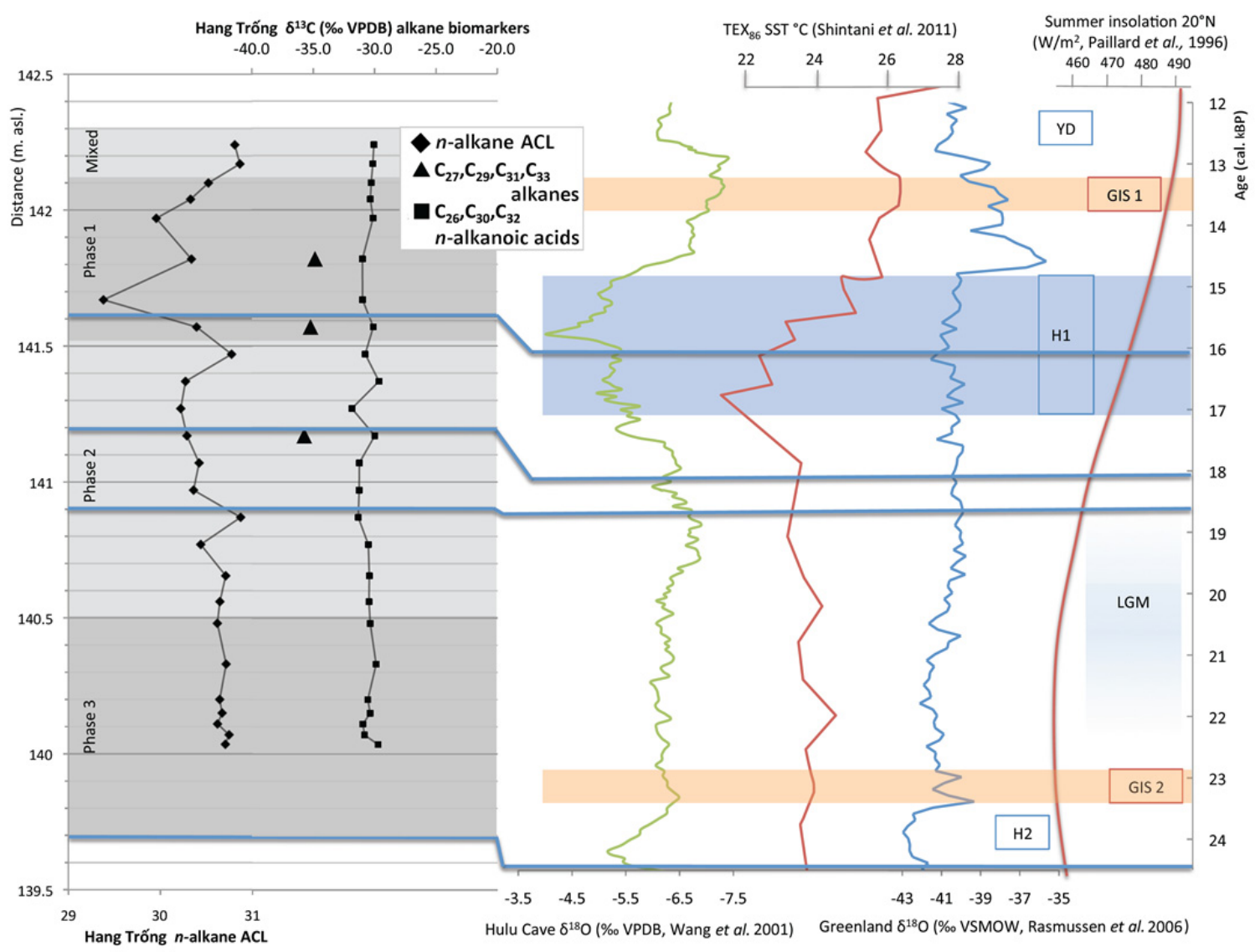

« Figure 4, n-Alkane data from Hang Trống compared to published palaeoarchive data during the LGM: thick horizontal lines indicate ${ }^{14} \mathrm{C}$ dates from Hang Trống at respective depths and ages along the cal. kBP scale. Hang Trống $\delta^{13} \mathrm{C}$ biomarkers display the consistent trend of $\mathrm{C}_{3}$ vegetation surrounding the site. Oxygen isotopes from Hulu cave have been shown to provide evidence of monsoonal changes, which coincide with sea surface temperature changes (SST) in the China Sea. Oxygen isotope records (Rasmussen et al. 2006) indicate global temperature changes, specifically Greenland Interstadial 1 (GIS 1 ) and GIS 2. Both oxygen isotope and SST records indicate little change during the LGM, during which time summer insolation values were low $\left(c .460 \mathrm{~W} / \mathrm{m}^{2}\right)$. $n$-Alkane average chain length values (ACL) from Hang Trống also display a consistent trend across the LGM. H1 (c. 15 kBP), however, sees a dramatic change: a drop in oxygen isotope values from Hulu Cave, SST from the South China Sea and ACL from Hang Trống. Drawing: N. Ludgate >> 
Hang Trống: Trench 1 North-facing section

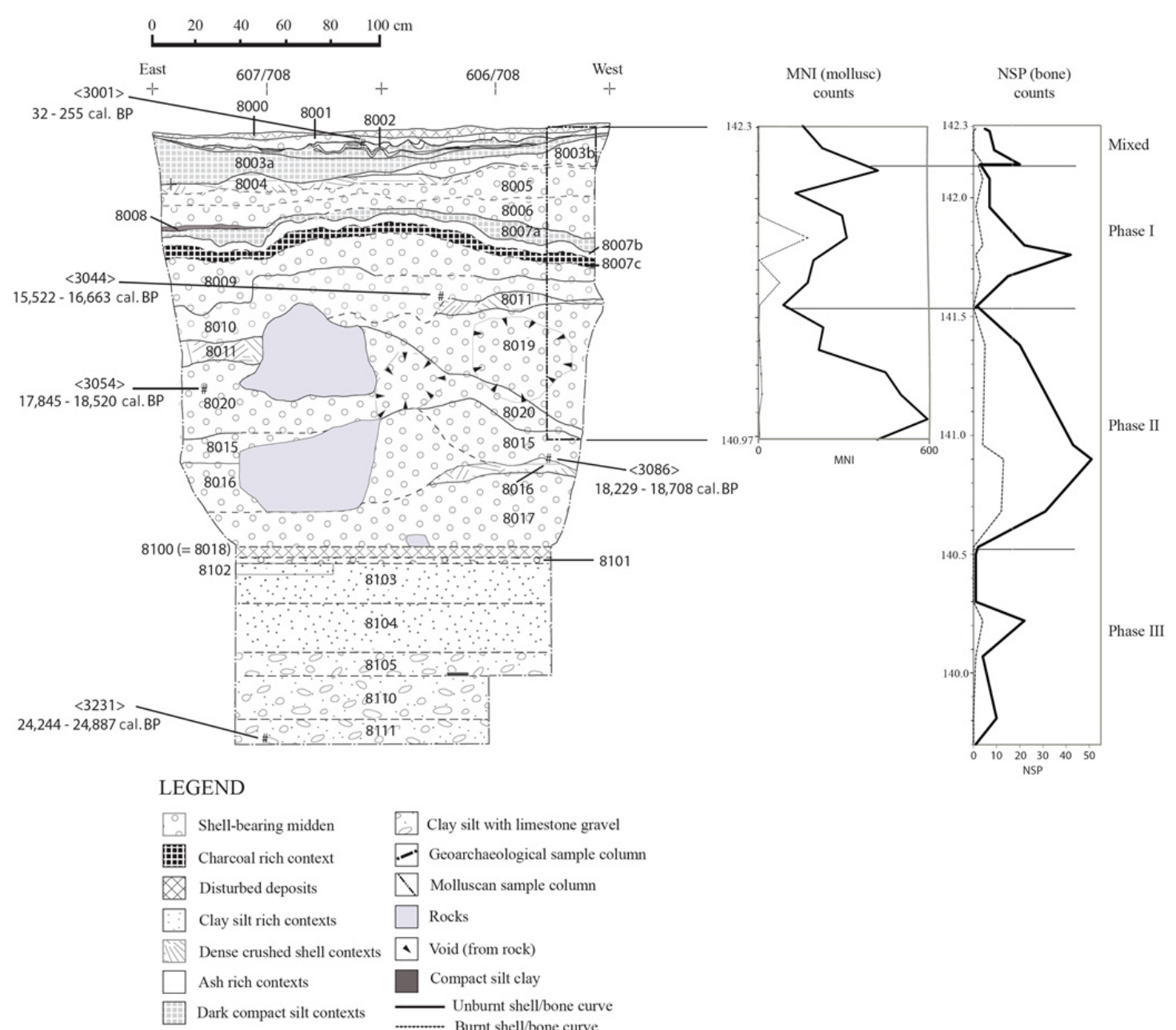

Figure 5, north-facing section of Trench 1 at Hang Trống, showing molluscan sample columns, molluscan (MNI) and vertebrate faunal (NSP) count curves (latter combining data from all three excavated trenches). Drawing: C. Stimpson and R. Rabett. >> 

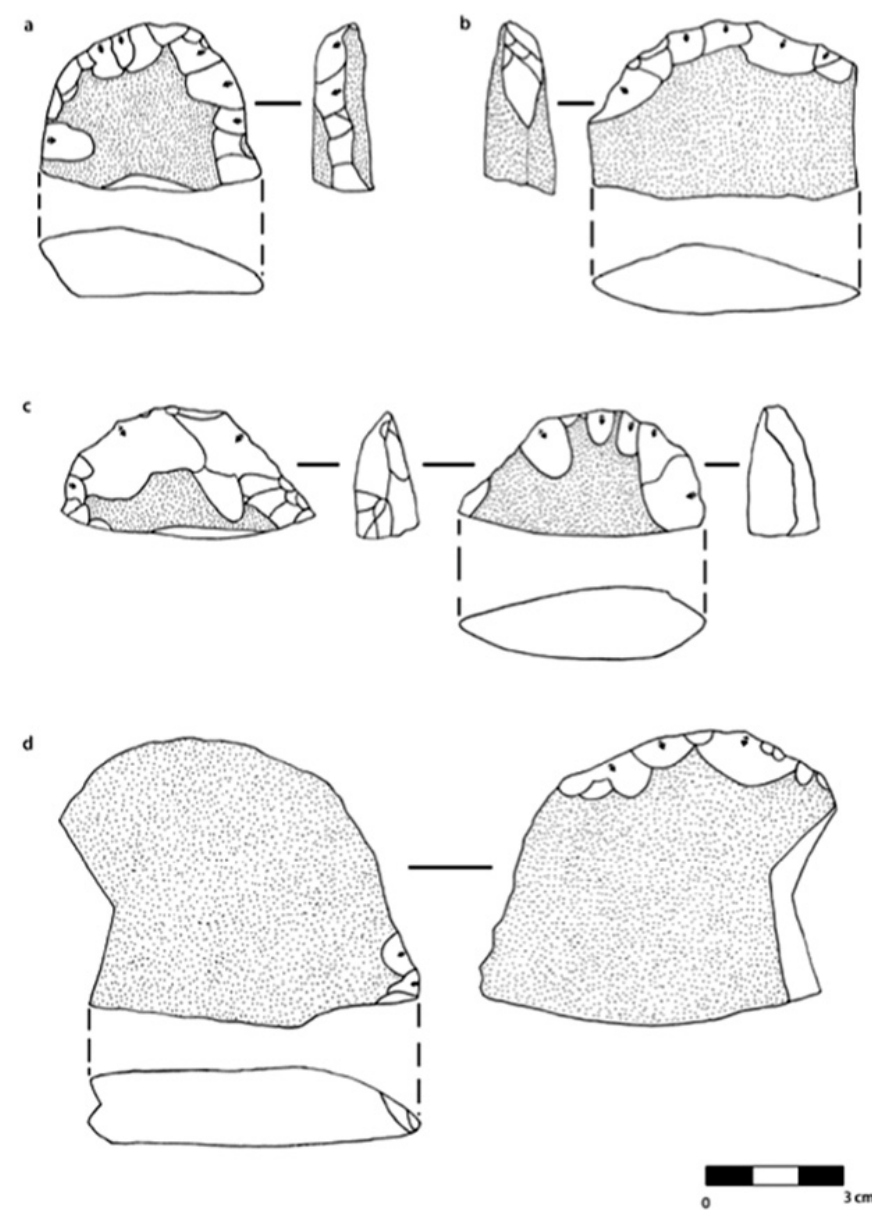

< Figure 6, examples of flaked pebble tools or 'short-axes' from Hang Trống: Artefact nos. 13 (a), 7 (b), 10 (c) and 46 (d) - see table 7. Drawing: L. Phan. $>>$ 


\begin{tabular}{cccccccc}
\hline Grid Square & Context & $\begin{array}{c}\text { Depth }(\mathbf{c m}) \\
\text { relative to datum }\end{array}$ & Material & $\begin{array}{c}\text { Radiocarbon } \\
\text { years BP }\end{array}$ & $\begin{array}{c}\text { Calibrated } \\
\text { years BP }\end{array}$ & Lab code & Year \\
\hline $607 / 708$ & 8001 & 142.25 & Charcoal & $80 \pm 17$ & $32-355$ & UBA-14883 & 2009 \\
Test pit & Layer 3 & Surface $-3 \mathrm{~cm}^{*}$ & Charcoal & $10,827 \pm 32$ & $12,594-12,854$ & UBA-09301 & 2007 \\
$610 / 715$ & 8308 & 142.00 & Charcoal & $12,363 \pm 51$ & $14,056-14,902$ & UBA-21288 & 2010 \\
$606 / 708$ & 8010 & 141.57 & Charcoal & $13,227 \pm 35$ & $15,522-16,663$ & UBA-14884 & 2009 \\
$607 / 708$ & $8013(=8020)$ & 141.22 & Charcoal & $14,878 \pm 45$ & $17,845-18,520$ & UBA-14885 & 2009 \\
$606 / 708$ & 8016 & 140.89 & Charcoal & $15,300 \pm 38$ & $18,229-18,708$ & UBA-14886 & 2009 \\
$606+607 / 709$ & 8111 & 139.71 & Charcoal & $20,537 \pm 61$ & $24,244-24,887$ & UBA-17272 & 2010 \\
\hline
\end{tabular}

$\ll$ Table 1, ${ }^{14} \mathrm{C}$ dates obtained from excavations at Hang Trống during 2007, 2009 and 2010 field-seasons; ${ }^{*}$ the shovel test pit depth measurement is approximate and not relative to site datum. All dates were calibrated using the CALIB 6.1.0 calibration curve (2-sigma). >> 


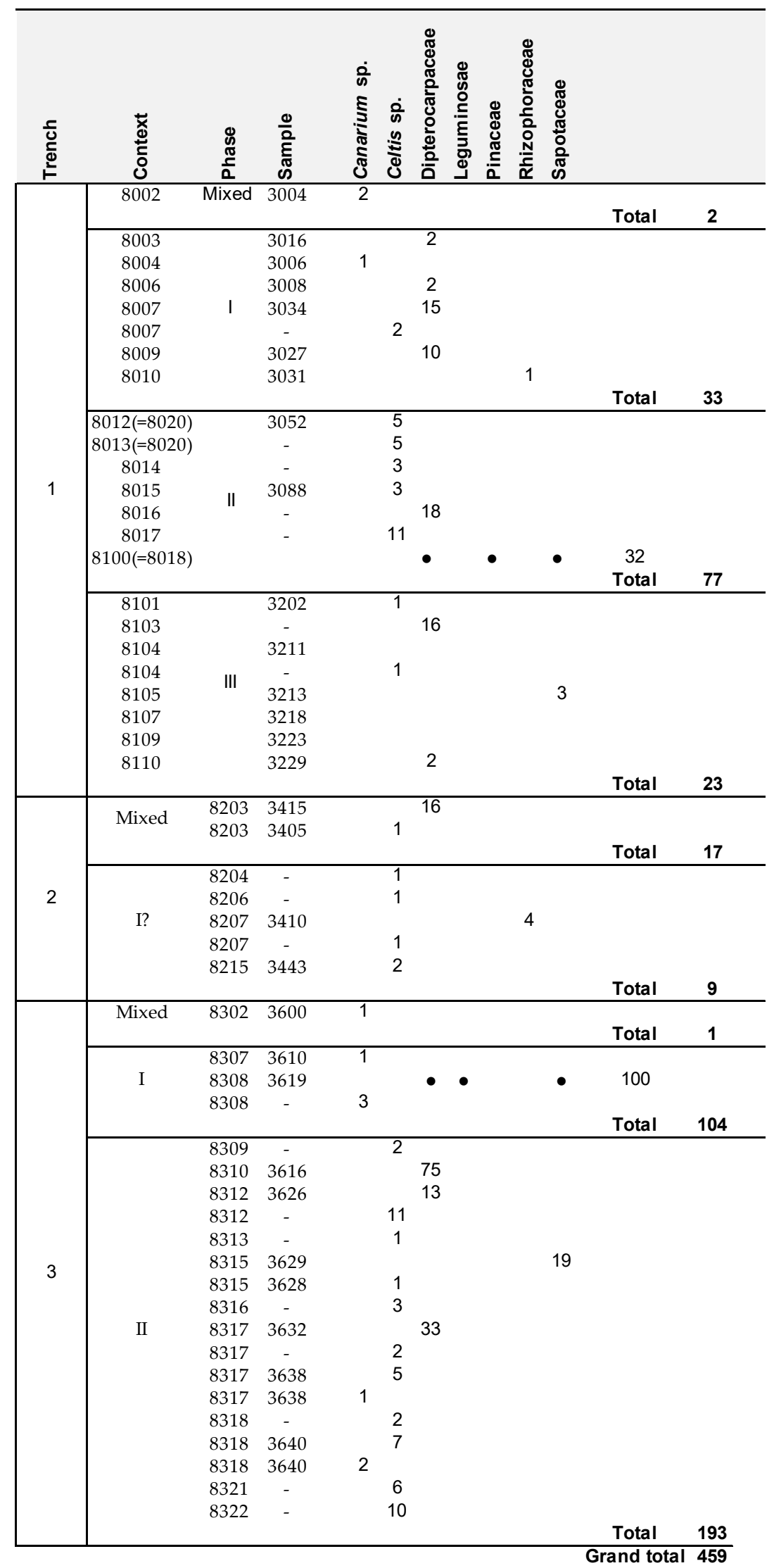

$\ll$ Table 2, identified macro-botanical remains $(n=459)$ from dry-sieving and flotation of sediments collected during the 2009 and 2010 excavations at Hang Trống; '•' proportion of individual identified taxa not recorded for these contexts. >> 


\begin{tabular}{|c|c|c|c|c|c|c|c|c|c|}
\hline 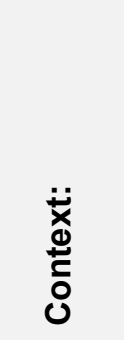 & 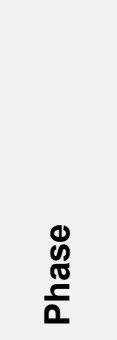 & 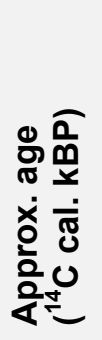 & $\begin{array}{l}\widehat{\underline{\xi}} \\
\bar{\xi} \\
\stackrel{0}{0}\end{array}$ & 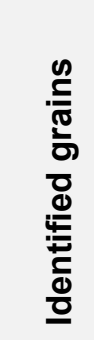 & 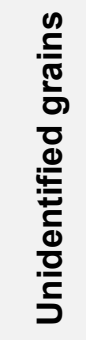 & 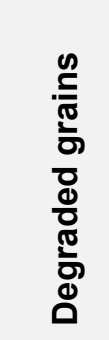 & 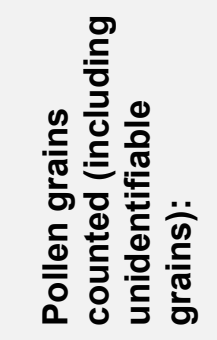 & 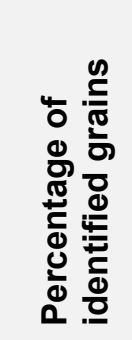 & 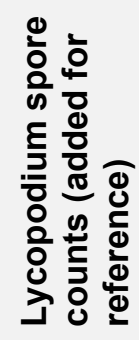 \\
\hline $\begin{array}{l}8000- \\
8002\end{array}$ & Mixed & 0 & 142.25 & 196 & 77 & 133 & 329 grains & $60 \%$ & 231 \\
\hline 8009 & 1 & 15.1 & 141.8 & 10 & 25 & 145 & 180 grains & $5.6 \%$ & 2003 \\
\hline 8010 & & 15.6 & 141.6 & 2 & 4 & 24 & 30 grains & $6.7 \%$ & 1000 \\
\hline 8016 & & 18.5 & 140.9 & 4 & 10 & 55 & 69 grains & $5.8 \%$ & 2008 \\
\hline 8019 & $\|$ & 17.1 & 141.4 & 22 & 9 & 505 & 536 grains & $4.1 \%$ & 513 \\
\hline 8019 & $\|$ & 17.6 & 141.3 & 5 & 5 & 175 & 185 grains & $2.7 \%$ & 1001 \\
\hline Totals: & & & & 239 & 130 & 1037 & 1329 grains & & \\
\hline
\end{tabular}

$<$ Table 3, pollen counts from the pilot study at Hang Trống. >> 


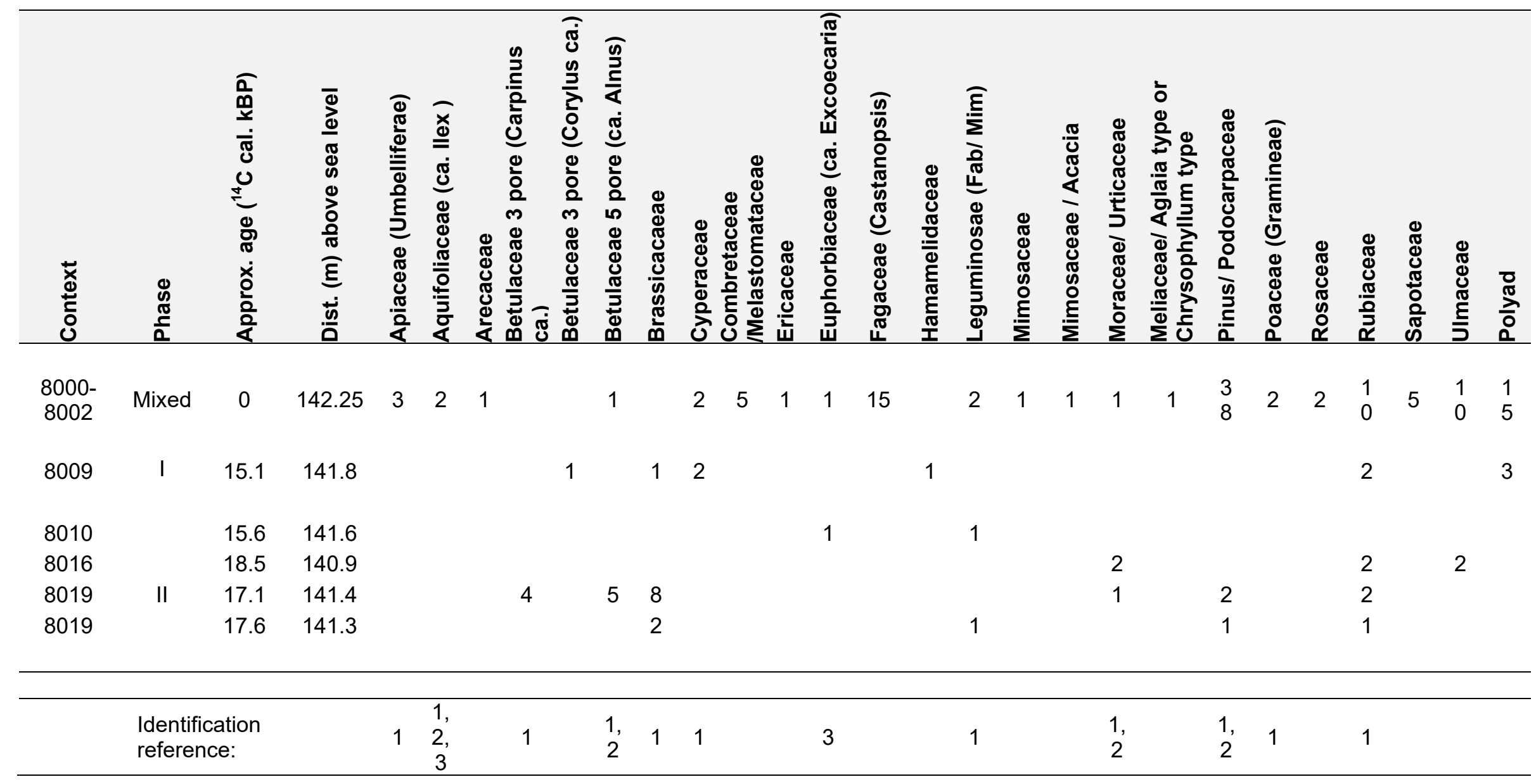

$\ll$ Table 4, pollen identification (Trench 1) from families identified using reference collections from Zhuo Zheng (pers. comm.), ${ }^{1}$ Tseng-Chieng (1972), ${ }^{2}$ Li et al. (2006a) and 3Institute of Botany (1982). >> 


\begin{tabular}{|c|c|c|c|c|c|c|c|c|c|c|c|c|c|}
\hline \multirow[t]{2}{*}{ Phase } & \multirow[t]{2}{*}{ Trench } & \multirow[t]{2}{*}{ Context } & \multirow{2}{*}{$\begin{array}{l}\text { Malacostraca } \\
\text { (crab) }\end{array}$} & \multirow{2}{*}{$\begin{array}{l}\text { Osteichthyes } \\
\text { (fish) }\end{array}$} & \multirow{2}{*}{$\begin{array}{c}\text { Amphibia } \\
\text { (amphibians) }\end{array}$} & \multirow{2}{*}{$\begin{array}{l}\text { Reptilia } \\
\text { (reptiles) }\end{array}$} & \multirow{2}{*}{$\begin{array}{c}\text { Aves } \\
\text { (birds) }\end{array}$} & \multicolumn{2}{|c|}{ Mammalia } & \multirow{2}{*}{$\begin{array}{l}\text { Total } \\
\text { NISP }\end{array}$} & NSP & Total & Burnt NSP \\
\hline & & & & & & & & (small) & (large) & & (large animal) & NSP & \\
\hline & 1 & 8000 & & & & & & 26 & 0 & 42 & 5 & 47 & 1 \\
\hline & 1 & 8001 & 0 & 0 & 0 & 0 & 0 & 0 & 1 & 1 & 6 & 7 & 0 \\
\hline & 1 & 8002 & 0 & 0 & 1 & 0 & 0 & 0 & 1 & 2 & 8 & 10 & 0 \\
\hline & 2 & 8200 & 0 & 0 & 47 & 0 & 3 & 34 & 0 & 84 & 4 & 88 & 0 \\
\hline Mixed & 2 & $8200-8201$ & 0 & 0 & 1 & 0 & 1 & 22 & 2 & 26 & 4 & 30 & 1 \\
\hline & 2 & 8201 & 0 & 0 & 1 & 0 & 5 & 9 & 1 & 16 & 11 & 27 & 0 \\
\hline & 2 & 8202 & 0 & 0 & 0 & 1 & 1 & 6 & 0 & 8 & 1 & 9 & 0 \\
\hline & 2 & 8203 & 2 & 2 & 1 & 0 & 0 & 1 & 1 & 7 & 35 & 42 & 1 \\
\hline & 3 & 8302 & 0 & 0 & 0 & 0 & 0 & 3 & 0 & 3 & 1 & 4 & 0 \\
\hline & & Totals & 2 & 2 & 62 & 2 & 14 & 101 & 6 & 189 & 75 & 264 & 3 \\
\hline & 1 & 8003 & 2 & 0 & 0 & 0 & 0 & 0 & 5 & 7 & 15 & 24 & 4 \\
\hline & 1 & 8004 & 0 & 0 & 0 & 0 & 0 & 0 & 0 & 0 & 3 & 3 & 2 \\
\hline & 1 & 8005 & 1 & 0 & 0 & 0 & 0 & 0 & 1 & 2 & 6 & 14 & 4 \\
\hline & 1 & 8006 & 1 & 0 & 0 & 0 & 0 & 0 & 1 & 2 & 6 & 8 & 1 \\
\hline & 1 & 8007 & 0 & 0 & 0 & 0 & 0 & 2 & 2 & 4 & 20 & 24 & 4 \\
\hline & 1 & 8009 & 0 & 0 & 0 & 0 & 0 & 3 & 18 & 21 & 24 & 47 & 1 \\
\hline & 2 & 8204 & 1 & 0 & 0 & 0 & 0 & 0 & 0 & 1 & 2 & 3 & 0 \\
\hline & 2 & 8205 & 0 & 0 & 0 & 0 & 0 & 0 & 0 & 0 & 3 & 5 & 2 \\
\hline & 2 & 8206 & 0 & 0 & 2 & 0 & 0 & 1 & 1 & 4 & 8 & 12 & 0 \\
\hline & 2 & 8207 & 0 & 0 & 0 & 0 & 0 & 1 & 1 & 2 & 6 & 8 & 0 \\
\hline Phase I & 2 & 8209 & 1 & 0 & 0 & 0 & 0 & 0 & 0 & 1 & 10 & 11 & 0 \\
\hline Pnase I & 2 & 8210 & 0 & 0 & 0 & 0 & 0 & 1 & 0 & 1 & 7 & 9 & 0 \\
\hline & 2 & $8210 / 8211$ & 0 & 0 & 0 & 0 & 0 & 0 & 1 & 1 & 2 & 3 & 0 \\
\hline & 2 & 8211 & 0 & 0 & 0 & 0 & 0 & 0 & 1 & 1 & 7 & 8 & 0 \\
\hline & 2 & 8212 & 0 & 0 & 0 & 0 & 0 & 0 & 2 & 2 & 5 & 7 & 0 \\
\hline & 2 & 8215 & 0 & 0 & 2 & 0 & 0 & 1 & 1 & 4 & 3 & 7 & 0 \\
\hline & 3 & 8303 & 6 & 0 & 0 & 0 & 0 & 0 & 1 & 7 & 11 & 18 & 1 \\
\hline & 3 & 8304 & 11 & 0 & 0 & 0 & 0 & 1 & 0 & 12 & 11 & 23 & 3 \\
\hline & 3 & 8305 & 0 & 0 & 0 & 0 & 0 & 0 & 1 & 1 & 8 & 9 & 2 \\
\hline & 3 & 8306 & 2 & 2 & 0 & 0 & 0 & 0 & 0 & 4 & 8 & 12 & 0 \\
\hline & 3 & 8307 & 4 & 1 & 0 & 0 & 0 & 0 & 2 & 7 & 28 & 35 & 12 \\
\hline & 3 & 8308 & 6 & 3 & 0 & 0 & 0 & 3 & 6 & 18 & 87 & 96 & 11 \\
\hline & & Totals & 35 & 6 & 4 & 0 & 0 & 13 & 44 & 102 & 280 & 386 & 47 \\
\hline & 1 & 8010 & 0 & 0 & 0 & 1 & 0 & 0 & 1 & 2 & 14 & 18 & 3 \\
\hline & 1 & 8011 & 0 & 0 & 0 & 0 & 0 & 0 & 0 & 0 & 1 & 2 & 0 \\
\hline & 1 & 8019 & 0 & 0 & 0 & 0 & 0 & 0 & 0 & 0 & 2 & 2 & 0 \\
\hline & 1 & 8020 & 1 & 0 & 0 & 0 & 2 & 0 & 4 & 7 & 16 & 23 & 5 \\
\hline & 1 & 8015 & 0 & 0 & 0 & 0 & 0 & 1 & 6 & 7 & 37 & 44 & 4 \\
\hline & 1 & 8016 & 0 & 0 & 0 & 0 & 0 & 1 & 6 & 7 & 45 & 52 & 13 \\
\hline & 1 & 8017 & 0 & 1 & 0 & 0 & 1 & 0 & 2 & 4 & 29 & 35 & 12 \\
\hline & 3 & 8309 & 0 & 0 & 0 & 0 & 0 & 0 & 1 & 1 & 10 & 11 & 0 \\
\hline & 3 & 8310 & 3 & 0 & 0 & 0 & 0 & 1 & 1 & 5 & 13 & 18 & 7 \\
\hline Phase I & 3 & 8311 & 0 & 0 & 0 & 0 & 0 & 0 & 0 & 0 & 3 & 3 & 0 \\
\hline Phase II & 3 & 8312 & 1 & 0 & 0 & 0 & 0 & 1 & 2 & 4 & 4 & 8 & 2 \\
\hline & 3 & 8313 & 0 & 0 & 0 & 0 & 0 & 0 & 0 & 0 & 2 & 2 & 0 \\
\hline & 3 & 8315 & 0 & 0 & 0 & 0 & 0 & 1 & 1 & 2 & 7 & 9 & 0 \\
\hline & 3 & 8316 & 1 & 0 & 0 & 0 & 0 & 0 & 2 & 3 & 6 & 9 & 2 \\
\hline & 3 & 8317 & 0 & 0 & 0 & 0 & 0 & 2 & 1 & 3 & 16 & 19 & 6 \\
\hline & 3 & 8318 & 0 & 0 & 0 & 0 & 0 & 0 & 1 & 1 & 1 & 1 & 0 \\
\hline & 3 & 8319 & 2 & 0 & 1 & 0 & 0 & 0 & 0 & 3 & 2 & 5 & 2 \\
\hline & 3 & 8321 & 0 & 0 & 0 & 0 & 0 & 0 & 6 & 6 & 52 & 58 & 18 \\
\hline & 3 & 8322 & 0 & 0 & 0 & 0 & 0 & 0 & 2 & 2 & 22 & 24 & 2 \\
\hline & 3 & 8323 & 0 & 0 & 0 & 0 & 0 & 0 & 0 & 0 & 2 & 2 & 1 \\
\hline & & Totals & 8 & 1 & 1 & 1 & 3 & 7 & 36 & 57 & 284 & 345 & 77 \\
\hline & 1 & $8018 / 8100$ & 0 & 0 & 0 & 0 & 0 & 0 & 1 & 1 & 1 & 2 & 0 \\
\hline & 1 & 8101 & 0 & 0 & 0 & 0 & 0 & 0 & 0 & 0 & 1 & 1 & 0 \\
\hline & 1 & 8102 & 0 & 0 & 0 & 0 & 0 & 0 & 0 & 0 & 0 & 0 & 0 \\
\hline Phase III & 1 & 8103 & 0 & 0 & 0 & 0 & 1 & 1 & 0 & 2 & 1 & 3 & 0 \\
\hline Phase III & 1 & $8104(=8109)$ & 0 & 0 & 0 & 0 & 0 & 0 & 1 & 1 & 14 & 15 & 4 \\
\hline & 1 & 8105 & 0 & 0 & 0 & 0 & 0 & 0 & 0 & 0 & 4 & 4 & 1 \\
\hline & 1 & 8110 & 0 & 0 & 0 & 0 & 0 & 0 & 1 & 1 & 9 & 10 & 0 \\
\hline & 1 & 8111 & 0 & 0 & 0 & 0 & 0 & 0 & 1 & 1 & 1 & 1 & 0 \\
\hline & & Totals & 0 & 0 & 0 & 0 & 1 & 1 & 4 & 6 & 31 & 36 & 5 \\
\hline
\end{tabular}

$\ll$ Table 5, vertebrate fauna remains from Hang Trong (2009 \& 2010) analysed from trenches 1-3 and from all four identified phases. $>>$ 


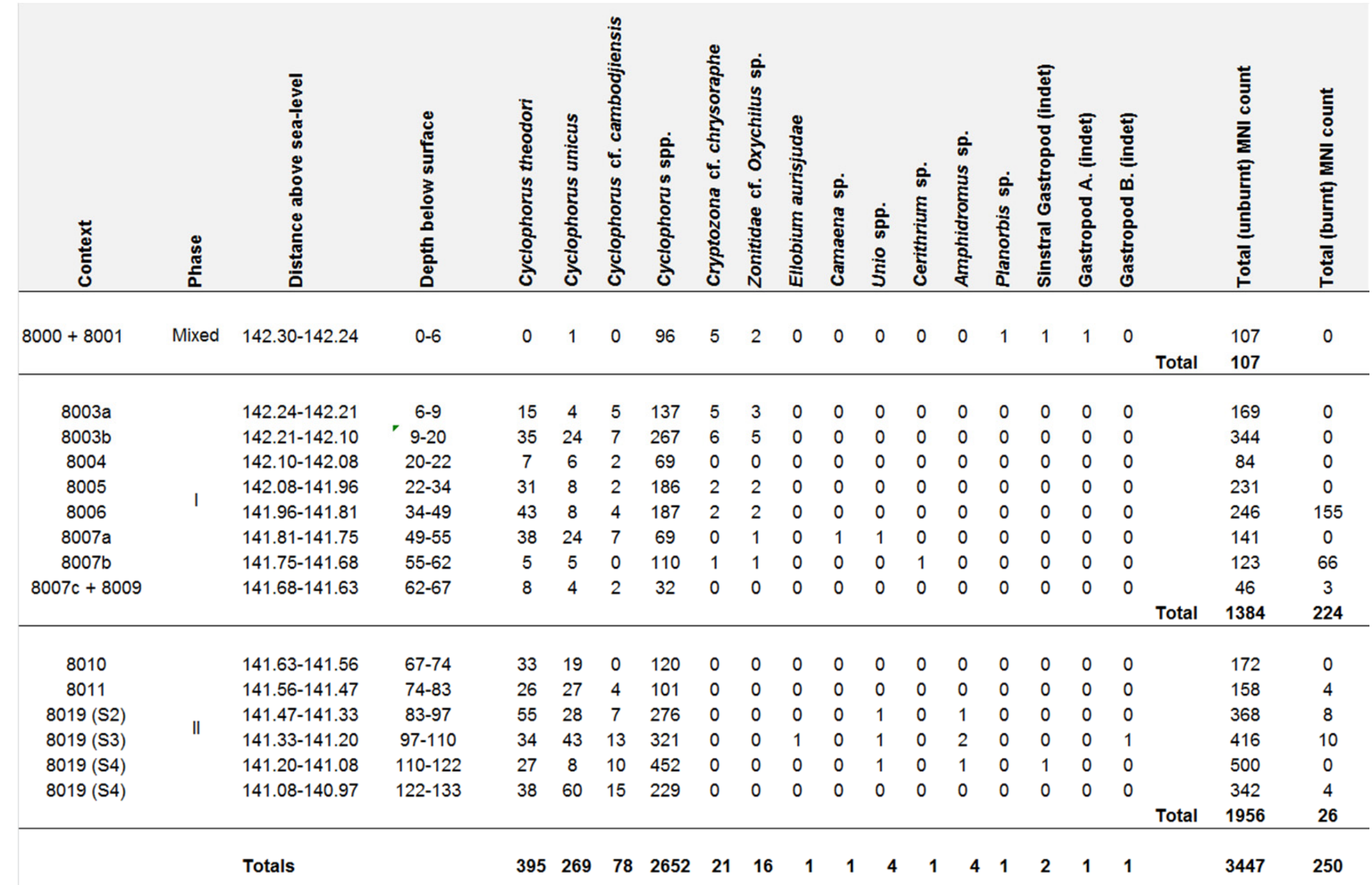

$<<$ Table 6, Hang Trống mollusc sample column from Trench 1, north-facing section: taxonomic identification and quantification by depth and sample number. $>$ 


\begin{tabular}{|c|c|c|c|c|c|c|c|c|c|c|}
\hline Trench/Square & Context & Phase & Techno-typological analysis & Attribute analysis & Typological ID & Raw material & Length & Width & Thickness & Comments \\
\hline Surface find & & & Secondary pebble fragment & & Short axe & Shale & 4.9 & 5.7 & 1.5 & Transverse snap forms butt of tool \\
\hline Deep Sounding & 8101 & & Secondary flake with cortical platform & Complete flake & & Limestone & 2.7 & 2.4 & 0.8 & \\
\hline Deep Sounding & 8101 & & Secondary flake with plain platform & Flake fragment & - & Limestone & 2 & 1.7 & 0.5 & Stepped \\
\hline Deep Sounding & 8101 & & Burnt pebble fragment & ? & - & Limestone & 4.7 & 2.7 & 1.4 & Burnt (natural?) \\
\hline Deep Sounding & 8101 & & Secondary flake with crushed platform & Complete flake & - & Limestone & 4.3 & 8.1 & 1.7 & - \\
\hline Deep Sounding & 8101 & & Flake core with single platform & Core & Core & Limestone & 6 & 6.2 & 3.2 & 4 removals \\
\hline Deep Sounding & 8103 & & Secondary pebble fragment & Pebble tool & Short axe & Limestone & 3.8 & 6.1 & 1.6 & Transverse snap forms butt of tool \\
\hline Deep Sounding & 8104 & & Pebble half fragment & Core/Pebble tool & Jivil ane & Sandstone & $\begin{array}{l}3.1 \\
3.1\end{array}$ & 3.7 & 1.4 & $\begin{array}{l}\text { Transverse snap } \\
\text { The }\end{array}$ \\
\hline Deep Sounding & 8104 & III & Pebble fragment burnt & Complete flake & & Limestone & 4.1 & 2.5 & 1.4 & burnt \\
\hline Deep Sounding & 8104 & III & Secondary bifacial pebble tool & Pebble tool & Short axe & Shale & 2.7 & 5.3 & 1.5 & Transverse snap forms butt of tool; bifacial edge trimming \\
\hline $607 / 709$ & Cleaning & & Secondary fragment & Pevole tour & Scraper & Limestone & 6.2 & 7.3 & 1.8 & Retouched natural fragment; transverse snap \\
\hline $606 / 709$ & 8109 & & Tertiary siret flake with crushed platform & Complete flake & - & Limestone & 3.4 & 2.5 & 1.9 & Half-moon snaps \\
\hline $607 / 709$ & 8110 & & Secondary pebble fragment & Pebble tool & Short axe & Shale & 3.7 & 4.9 & 1.3 & Flattened pebble \\
\hline $606 / 709$ & 8110 & & Plain platform tertiary flake & Complete flake & - & Shale & 3.2 & 3.4 & 0.9 & - \\
\hline $607 / 709$ & 8110 & & Secondary flake with plain platform & Complete flake & - & Shale & 1.7 & 3.1 & 0.6 & Off pebble \\
\hline $606 / 709$ & 8110 & & Secondary flake with cortical platform & Complete flake & - & Limestone & 2.2 & 2.9 & 0.7 & Off pebble \\
\hline $609 / 709$ & $8110 / 8105$ & & Tertiary flake with crushed platform & Retouched flake & Scraper & Quartzite & 2.2 & 2.5 & 0.7 & Stepped \\
\hline $601 / 712$ & 8200 & & Flaked pebble fragment & Core & Core? & Limestone & 3.8 & 5.3 & 6.3 & Steep edged; platform on each end; stepped flaking removals \\
\hline $601 / 712$ & 8200 & & Distal tertiary flake fragment & Complete flake & & Shale & 2 & 2.4 & 0.4 & Transverse snap \\
\hline $601 / 712$ & 8200 & & Distal tertiary flake fragment & Complete flake & - & Shale & 1.6 & 2.5 & 0.4 & \\
\hline $602 / 712$ & 8201 & Mixed & Tertiary flake with plain plafform & Complete flake & - & Limestone & 1.7 & 1.3 & 0.6 & Edge snaps \\
\hline $603 / 712$ & $8200 / 8201$ & Mixea & Tertiary flake with crushed platform & Complete flake & - & Limestone & 3.5 & 2.7 & 0.6 & Oblique transverse snap; half-moon snaps \\
\hline $603 / 712$ & $8200 / 8201$ & & Tertiary flake with crushed platform & Complete flake & - & Limestone & 2.9 & 2.6 & 0.6 & Edge snaps \\
\hline $601 / 712$ & 8203 & & Distal primary flake fragment & Flake fragment & - & Shale & 3.2 & 3.2 & 0.8 & Transwerse snap \\
\hline $602 / 712$ & 8203 & & Elongate pebble fragment & & - & Shale & 5.8 & 4.9 & 2.6 & Natural? \\
\hline $603 / 712$ & 8207 & & Tertiary shatter fragment & - & - & Shale & 2.4 & 1.5 & 0.7 & Natural? \\
\hline $603 / 712$ & 8209 & I? & Tertiary flake with plain platform & & & Shale & 2.5 & 4.5 & 0.8 & \\
\hline $603 / 712$ & 8211 & & Distal tertiary flake/blade fragment & Complete flake & - & Shale & 2 & 1.3 & 0.4 & Transverse snap \\
\hline $609 / 714$ & 8300 & Mixed & Secondary pebble flaked fragment & Pebble tool & Short axe & Limestone & 7.8 & 9.5 & 3.2 & Transverse snap forms butt of tool \\
\hline $610 / 715$ & & & & & & & & & & \\
\hline $\begin{array}{l}610 / 715 \\
610 / 715\end{array}$ & $\begin{array}{l}8303 \\
8303\end{array}$ & & $\begin{array}{l}\text { Secondary flake with crushed plafform } \\
\text { Secondary pebble fragment }\end{array}$ & Complete flake & - & $\begin{array}{l}\text { Limestone } \\
?\end{array}$ & $\begin{array}{l}2.6 \\
4.1\end{array}$ & $\begin{array}{c}2.7 \\
3\end{array}$ & $\begin{array}{l}0.3 \\
1.2\end{array}$ & $\begin{array}{l}\text { Edge snaps } \\
\text { Heavily burnt }\end{array}$ \\
\hline $610 / 715$ & 8303 & & Secondary flake with crushed platform & Complete flake & - & Limestone & 1.4 & 1.6 & 0.1 & Edge snaps \\
\hline $610 / 715$ & 8304 & & Distal tertiary flake fragment & Flake fragment & - & Shale & 2.2 & 1.8 & 0.3 & Transverse snap and edge flaking off it \\
\hline $610 / 715$ & 8304 & & Tertiary shatter fragment & & - & Limestone & 1.7 & 2.4 & 0.5 & Natural? \\
\hline $610 / 714$ & 8304 & & Secondary fragment & - & - & Shale & & 2. & (3) & Natural? \\
\hline $610 / 714$ & 8304 & & Flake with plain platform & Complete flake & - & Limestone & 3.4 & 4.4 & 0.7 & Stepped; edge damage \\
\hline $610 / 714$ & 8304 & & Tertiary pebble fragment & 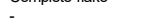 & 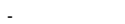 & Limestone & 0.7 & 7.7 & 0.1 & Natural? \\
\hline $610 / 715$ & 8305 & & Pebble single platform flake core & Core & Core & Limestone & 3.5 & 5.3 & 9.4 & Elongate pebble; 4 removals \\
\hline $610 / 715$ & 8305 & & Tertiary flake with crushed platform & Complete flake & & Shale & 1.6 & 1.3 & 0.3 & \\
\hline $610 / 715$ & 8306 & & Distal tertiary flake fragment & ? & - & Shale & 1 & 1.8 & 0.2 & Transverse and edge snaps \\
\hline $610 / 714$ & 8307 & I & Secondary flake with cortical platform & Complete flake & - & Shale & 3.6 & 2.6 & 0.8 & - \\
\hline $610 / 714$ & 8307 & 1 & Distal primary blade fragment & Complete flake & Burin & Shale & 4.2 & 1.5 & 0.8 & - \\
\hline $610 / 714$ & 8307 & & Tertiary flake fragment with cortical & Flake fragment & - & $\begin{array}{l}\text { Shale } \\
\text { Shale }\end{array}$ & 1.5 & 1.2 & 0.4 & - \\
\hline $610 / 714$ & 8307 & & Distal tertiary flake fragment & Flake fragment & - & $\begin{array}{l}\text { Shale } \\
\text { Shale }\end{array}$ & 1.3 & 1.2 & 0.4 & - \\
\hline $610 / 714$ & 8307 & & Secondary shatter fragment & ride ingrierit & - & $\begin{array}{l}\text { Shale } \\
\text { Shale }\end{array}$ & 3.2 & 1.8 & 0.6 & Natural? \\
\hline $609 / 716$ & 8308 & & Retouched pebble fragment & Pebble tool & Short axe & $\begin{array}{l}\text { Shale } \\
\text { Shale }\end{array}$ & $\begin{array}{l}3.2 \\
6.4\end{array}$ & $\begin{array}{l}1.0 \\
6.4\end{array}$ & 1.8 & Flattish pebble \\
\hline $609 / 716$ & $\begin{array}{l}8300 \\
8308\end{array}$ & & Tertiary flake fragment with cortical & - & Silorlaxe & $\begin{array}{l}\text { Shale } \\
\text { Shale }\end{array}$ & $\begin{array}{l}0.4 \\
6.5\end{array}$ & $\begin{array}{l}0.4 \\
4.4\end{array}$ & 1.1 & Half-moon snaps \\
\hline $610 / 715$ & 8308 & & Flaked secondary pebble chopper/core & Pebble tool & Chopper & Shale & 6.4 & 9.8 & 3.9 & 6 flake removals if this was core \\
\hline $610 / 715$ & 8308 & & Secondary flake with crushed platform & Complete flake & & Shale & 2.3 & 2.8 & 0.5 & \\
\hline $610 / 715$ & 8308 & & Secondary flake with crushed platform & Complete flake & & Shale & 1.7 & 2.8 & 0.3 & - \\
\hline $610 / 715$ & 8308 & & Secondary flake with plain platform & Complete flake & & Shale & 2.2 & 3.4 & 0.8 & - \\
\hline $610 / 715$ & 8308 & & Pebble & Pebble tool & Pounder & Limestone & 9.6 & 9.1 & 6.7 & Battering + flaking damage (opposed ends) \\
\hline $610 / 714$ & 8309 & & Tertiary flake with plain platform & Complete flake & - & Shale & 1.3 & 1.8 & 0.5 & - \\
\hline $610 / 715$ & 8312 & & Tertiary flake with crushed platform & Complete flake & - & Shale & 4.1 & 3.6 & 0.9 & Lateral snaps \\
\hline $610 / 715$ & 8312 & & Primary flake with cortical platform & Complete flake & - & Shale & 2.4 & 3.7 & 0.7 & Half-moon snaps \\
\hline $610 / 715$ & 8312 & & Tertiary blade/flake with crushed & Complete flake & - & Shale & 2.5 & 1.4 & 0.3 & - \\
\hline $610 / 715$ & 8312 & & Tertiary flake with crushed platform & Flake fragment & - & Shale & 2.1 & 4.1 & 0.5 & Large half- moon snaps \\
\hline $610 / 715$ & 8312 & & Tertiary potilid & & - & Shale & 1.3 & 2 & 0.3 & Natural? \\
\hline $610 / 715$ & 8313 & & Tertiary flake with crushed platform & Complete flake & - & Shale & 2.3 & 4.5 & 0.8 & - \\
\hline $610 / 714$ & 8315 & & Secondary siret flake with cortical & Complete flake & - & Shale & 3.4 & 2.6 & 1.1 & - \\
\hline $610 / 714$ & 8315 & & Secondary flake with cortical platform & Complete flake & - & Shale & 3.6 & 6.3 & 1.4 & - \\
\hline $610 / 714$ & 8315 & & Tertiary flake with crushed platform & Complete flake & - & Shale & 3.2 & 2.5 & 0.7 & - \\
\hline $610 / 714$ & 8315 & & Secondary shatter fragment & & & Shale & 2.8 & 2.1 & 0.6 & Natural? \\
\hline $610 / 714$ & 8315 & & Tertiary flake fragment & Flake fragment & - & Limestone & 1.9 & 3.6 & 0.6 & Snapped around whole edge \\
\hline $610 / 714$ & 8315 & & Distal tertiary flake fragment & Flake fragment & - & Limestone & 2.3 & 2.3 & 0.3 & Transverse and edge snaps \\
\hline $610 / 714$ & 8315 & & Tertiary potlid & - & - & Limestone & 1.4 & 1.7 & 0.3 & Edge snaps (natural) \\
\hline $610 / 714$ & 8315 & & Tertiary flake with plain platform & - & - & Shale & 1.3 & 2.5 & 0.5 & Stepped \\
\hline $610 / 714$ & 8315 & & Tertiary shatter fragment & - & - & Shale & 1.6 & 2.1 & 0.3 & Flaking debris or natural? \\
\hline $610 / 714$ & 8315 & & Distal tertiary flake fragment & Flake fragment & - & Shale & 1.2 & 2.1 & 0.3 & Transverse snap \\
\hline $610 / 714$ & 8316 & ॥ & Tertiary flake with crushed platform & Complete flake & - & Shale & 2.2 & 2.2 & 0.2 & Hinged \\
\hline $610 / 714$ & 8317 & & Primary siret flake with crushed platform & Flake fragment & - & Shale & 2.4 & 1.5 & 0.7 & Half-moon snaps \\
\hline $609 / 715$ & 8322 & & Secondary flake with plain platform & Flake fragment & - & Shale & 0.9 & 3.2 & 0.8 & \\
\hline $609 / 715$ & 8322 & & Tertiary shatter fragment & - & - & Sha & 1.8 & 2.5 & 0.2 & Natural? \\
\hline $609 / 715$ & 8322 & & Tertiary s & - & ( & Sh & 2.6 & 1.7 & .5 & \\
\hline $609 / 715$ & 8322 & & Tertiary shatter fragment & - & & Sha & 3 & 1.8 & 0.8 & Natural? \\
\hline 609 & 8322 & & with plain platform & - & - & Shale & 2.8 & 2.9 & 0.7 & - \\
\hline & 8322 & & Tertiary flake with crushed platform & - & - & Sh & 2.2 & 2.6 & 0.9 & - \\
\hline 609 & 8322 & & Tertiary flake with crushed platform & - & - & Sha & 2.4 & 3.2 & 0.5 & - \\
\hline $609 / 715$ & 8322 & & Distal tertiary flake fragment & & - & Sh & 1.8 & 1.8 & 0.6 & . \\
\hline 609 & 8322 & & e with plain $p$ & Flake fragment & - & Sh & 1.4 & 1.4 & 0.3 & - \\
\hline $609 / 715$ & 8322 & & Distal tertiary flake fragment & Complete flake & - & Sh & 1.2 & 2 & 0.5 & Transverse snap \\
\hline $609 / 715$ & 8322 & & Distal tertiary flake fragment & & - & Sh & 1.4 & 2.4 & 0.3 & Transverse snap \\
\hline $609 / 715$ & 8322 & & Distal tertiary flake fragment & Flake fragment & 烈 & Sh & 1.4 & 1.5 & 0.2 & Transverse snap \\
\hline $609 / 715$ & 8322 & & Tertiary flake with plain platform & & - & Shale & 1.6 & 2.2 & 0.4 & - \\
\hline $609 / 715$ & 8322 & & Distal tertiary flake fragment & Flake fragment & - & Shale & 1.2 & 1.7 & 0.4 & - \\
\hline $609 / 715$ & 8322 & & Distal tertiary flake fragment & & - & Shale & 1.3 & 1.5 & 0.2 & - \\
\hline $610 / 715$ & 8322 & & Secondary pebble fragment, retouched & Pebble tool & Short axe & Shale & 4.6 & 6.4 & 1.8 & Transverse snap forms butt of tool \\
\hline
\end{tabular}

< Table 7, classification of material excavated in 2010 from Trench 1 (Phase III) and Trenches 2 and 3 (all represented deposition phases) using data generated separately by techno-typological and attribute analysis methods; classic typological referents are also given where relevant. >> 